\title{
REVALUING RESTITUTION: FROM THE TALMUD TO POSTSOCIALISM
}

\author{
Michael Heller* and Christopher Serkin**
}

Unuust Enrichment: A Study of Private Law and Public Values. By Hanoch Dagan. Cambridge, Eng.: Cambridge University Press. 1998. Pp. 185. $\$ 59.95$.

\section{TABle of Contents}

I. INTRODUCTION............................ 1385

II. RoAdmap to Restitution................... 1388

A. The Argument in Brief..................... 1388

B. The Translation Scheme.................. 1389

1. Definitions ......................... 1389

2. American Law Application .............. 1390

C. Restitution and National Ethos .............. 1393

III. Putting Restitution to the Test............. 1397

A. The Relationship Between Privatization and

Restitution ............................. 1397

B. The Variety of Restitution ................. 1399

1. Restitution in the Czech Republic ......... 1399

2. Restitution in Hungary .................. 1402

C. Gaps in the Existing Literature.............. 1403

1. Why Restitute Property At All? .......... 1403

2. Why Natural Restitution? ............... 1405

D. Postsocialist Restitution Through the Dagan

Prism .................................. 1407

1. Of Control and Well-Being.............. 1407

2. Eastern Europe and the "Personhood" of Property ............................ 1409

3. The Ethos of Expropriation............. 1410

IV. Conclusion .............................. 1412

\section{INTRODUCTION}

Whatever happened to the study of restitution? Once a core private law subject along with property, torts, and contracts, restitu-

* Assistant Professor of Law, University of Michigan Law School. - Ed.

** J.D. 1999, University of Michigan. - Ed. 
tion has receded from American legal scholarship. ${ }^{1}$ Few law professors teach the material, fewer still write in the area, and no one even agrees what the field comprises anymore. ${ }^{2}$ Hanoch Dagan's Unjust Enrichment: A Study of Private Law and Public Values $^{3}$ threatens to reverse the tide and make restitution interesting again. The book takes commonplace words such as "value" and "gain" and shows how they embody a society's underlying normative principles. Variations across cultures in the law of unjust enrichment reflect differences in national understandings of sharing, property, and even personhood. As Dagan puts it, he seeks "the reflection of core social values in the technicalities of the law" (p. 1).

The law at issue can be briefly summarized (and its more tedious complexities elided). Imagine, for example, someone chops trees from your land. Tort and contract law focus on remedying your loss. The law of unjust enrichment, however, is primarily concerned with restoring to you the trespasser's gain from using the lumber. Dagan's book reveals a complex inquiry hiding behind this simple distinction. Measuring restitution by the defendant's gain is a prologue to the further analysis of how a society understands value. Within the American legal system, the tree-chopper's gain may be defined as the lumber's fair market value, or can be calculated in terms of the chopper's net profits, the full proceeds from sale, or by a range of increasingly abstract methods. Within a single legal system, these various measures may all be available, each linked to restitution of a particular type of resource, each animated by different normative concerns. Dagan argues that restitutionary choices within a culture track attitudes towards property and personhood; overarching patterns across cultures reflect divergent national ethoses. Restitution is a window into a larger project of social understanding.

1. See, e.g., Andrew Kull, Rationalizing Restitution, 83 CAL. L. REv. 1191, 1191 (1995) ("Few American lawyers, judges, or law professors are familiar with even the standard propositions of the doctrine. ..." (emphasis omitted)).

2. See Richard A. Epstein, The Ubiquity of the Benefit Principle, 67 S. CAL. L. REv. 1369, 1371 (1994) ("At one point restitution was a standard course in the upper-year curriculum, but over time and with the ever greater expansion of public law subjects, it has slowly disappeared from view, being subsumed in a more general course on remedies, or taught in the interstices of the basic law of property, tort, and contract."); Kull, supra note 1, at 1195 n.14 (noting that restitution was a standard part of the law curriculum a generation ago, but only a "bare handful of American law schools" offer the course today); Saul Levmore, Explaining Restitution, 71 U. VA. L. REv. 65, 65 (1985) ("There is probably no greater set of surprising results and inconsistent maxims in private law than that formed by cases dealing with claims for payment made by providers of 'non-bargained benefits' to silent or disclaiming recipients.").

3. Hanoch Dagan is a Senior Lecturer, Tel Aviv University Faculty of Law and a Visiting Professor of Law, University of Michigan Law School. 
In this review we put Dagan's jurisprudential approach to a practical test. ${ }^{4}$ Restitution is going global; today, the postcommunist rebuilding of market economies, social developments in South Africa and Cuba, and even Native American and AfricanAmerican claims are at the cutting edge of restitution. ${ }^{5}$ We focus on Eastern Europe, where the Czechs are putting elderly people back into their childhood apartments, while the Hungarians offer compensation coupons for use in privatization auctions. ${ }^{6}$ Governments are valuing the unjust gains of - and more often the losses inflicted by - the communists in radically different ways as they attempt to reconnect with a precommunist past. Yet little theoretical work explains the rise of and variations among these massive programs of property reallocation. ${ }^{7}$

If Dagan's theory makes sense, and we think it does, then his book can provide some order for the hodgepodge of national mythmaking, political accident, and cultural posturing that surrounds the restitution frenzy in newly emerging market economies. ${ }^{8}$ His framework helps explain postcommunist restitutionary programs and points to some surprising results: more aggressive restitution may prove less protective of private property rights. In turn, the Eastern European experience challenges Dagan's portrayal of

4. A wholly different review of Dagan's book could be written, parsing his jurisprudential argument on selfhood and altruism in relation to Thomas Nagel, Duncan Kennedy, Joseph Raz, Ernest Weinrib, and a full host of legal philosophers. We are more practically minded folk and therefore commend our jurisprudentially oriented colleagues to Dagan's text itself, particularly Chapters 2 and 3.

5. See, e.g., Frances H. Foster, Restitution of Expropriated Property: Post-Soviet Lessons for Cuba, 34 Colum. J. Transnatu. L. 621 (1996); Nell Jessup Newton, Compensation, Reparations, \& Restitution: Indian Property Claims in the United States, 28 GA. L. REv. 453 (1994); Irma Jacqueline Ozer, Reparations for African Americans, 41 How. L.J. 479 (1998); Rob Nixon, White Farms, Black Claims, N.Y. TIMES, May 31, 1994, at A17.

6. See Cheryl Gray, The Legal Framework for Private Sector Activity in the Czech Republic, 26 Vand. J. Transnatl. L. 271 (1993) (discussing Czech restitution); Cheryl Gray, Rebecca Hanson \& Michael Heller, Hungarian Legal Reform for the Private Sector, 26 Geo. WASH. J. INTL. L. \& ECON. 293, 308-10 (1992) (outlining the coupon compensation program).

7. Postsocialist restitution scholarship is predominantly descriptive. See, e.g., infra note 22. Perhaps the best theoretical discussion is provided by Claus Offe, Disqualification, Retribution, Restitution: Dilemmas of Justice in Post-Communist Transitions, $1 \mathrm{~J}$. Pol. PHIL. 17 (1993).

8. One might argue that postsocialist restitution does not fit within a technical unjust enrichment paradigm. See Kull, supra note 1, at 1212-22 (arguing that restoration of resources is not part of unjust enrichment). Restoration of property to former owners seems more concerned with remedying the plaintiffs' losses than undoing the defendant communists' gains. This approach, however, may sound in unjust enrichment law when harm exceeds gain, as was typical in socialist societies. For Dagan's position, see p. 17 (arguing that plaintiff's harm can be a restitutionary remedy). Many leading commentators have placed restoration squarely within the law of unjust enrichment. See John P. Dawson, Restitution Without Enrichment, 61 B.U. L. REv. 563, 610 (1981); Douglas Laycock, The Scope and Significance of Restitution, 67 TeXAs L. REv. 1277, 1284 (1989). We do not see much point in this hyper-formal taxonomic debate. Dagan's method proves useful whether postsocialist restitution is restitution rightly considered or something else. 
the feel-good ethos of sharing by suggesting a richer and more troubling take on the meaning of community. By distilling doctrinal complexity through a sensitive jurisprudential filter, Dagan offers a new way to study private law.

\section{ROAdMAP to REstitution}

\section{A. The Argument in Brief}

Dagan's book is an easy read. Without too many bows to past masters, the book is cleanly written and tightly argued. The Prologue encapsulates the story, while the following chapters are a disciplined march through his theory concluding with concrete applications to and comparisons among American, Talmudic, and international law.

From a large range of available restitution paradigms, Dagan focuses solely on the example of $a$ defendant who is unjustly enriched by using a plaintiff's resource. ${ }^{9}$ Dagan avoids difficulties defining the scope of unjust enrichment in either the American or comparative setting because his goal is to "abstract[] from the contextual contingencies of any specific set of restitutionary rules, and to extricate the essence - the common denominator - of the ways various societies implement the general principle against unjust enrichment" (p. 3). Across cultures and spanning a breadth of resources, social values are reflected in methods of valuation. This is more than a clever semantic point; by linking available measures of recovery with specific social values, Dagan provides a "translation scheme" for interpreting the meaning of valuation, summarized usefully in a simple table (p. 22).

Dagan has two distinct projects in uneasy relation to each other. The first project is to explain variations in restitutionary remedies within a single culture. He relates those variations to the divergent rationales a society may seek to vindicate across a range of socially important resources. For example, Chapter Four sets out a detailed intracultural analysis of Americans' relationship with various resources. The more the specific property implicates its owner's "personhood" - like her body, her land, or maybe her car - the more likely the legal system will be to protect her control over the property rather than merely to restore her ex ante well-being.

The second project is more ambitious yet: to look across national legal systems and show how distinct national ethoses animate broader restitutionary patterns. Chapters Five and Six make this

9. This form of restitution is often referred to as "restitution for wrongs" and is conceptually, if not analytically, distinct from cases in which a plaintiff confers a benefit on a defendant. See, e.g., ANDREw Burrows \& EWAN McKendrick, Cases and Materials on the LAW OF RESTITUTION 569 (1997). 
comparison as they explore Talmudic civil law and international law respectively. While Dagan's first project strikes us as more compelling than the second, both parts of his effort contribute to revaluing restitution as a field for theoretical work.

\section{B. The Translation Scheme}

\section{Definitions}

Measures of restitutionary recovery range from the harm suffered by a plaintiff to several types of gain secured by a defendant. Gain, in turn, can mean quite different things, depending on the doctrinal niche in which the term is invoked. Gain can mean the fair market value of the appropriated resource or the defendant's net profits. It can refer to a defendant's gross proceeds from using an appropriated resource, in which case the defendant will be made worse-off than before she was unjustly enriched (assuming nonzero expenses in using the resource). Or gain can be measured as the greater or lesser of any combination of these values. Dagan points out that the ex post method of valuation will affect how vigorously people's resources are protected ex ante from appropriation and will signal a society's tolerance for appropriating another's property (p. 15). With the lowest measure of gain, defendants may readily appropriate resources they believe they can put to better use than the plaintiff; with the highest measure of gain, defendants may hesitate to take resources despite being confident their uses are more highly valued.

The question raised by the wide variety of restitutionary remedies is why, for any given resource, a legal system would choose one remedy over another. Dagan suggests that the specific measures of recovery noted above express various rationales that a society may be trying to vindicate, specifically well-being, control, sharing, and condemnation ( $\mathrm{pp} .15-16,22$ ). The argument concentrates primarily on well-being and control, which are defined by reference to the familiar distinction between "liability" and "property" rules.10 Well-being mirrors a liability rule in which "ex post pecuniary recovery is intended as a surrogate for ex ante consent" (p. 15). This rationale maintains an individual's initial level of wealth. Control, by contrast, mirrors a property rule by requiring the resource holder's ex ante consent before the resource may be taken. While restitution operates in a sphere in which a forced transfer has already occurred, certain rules for recovery can actually vindicate $e x$ ante control over resources by deterring invasions.

10. See Guido Calabresi \& A. Douglas Melamed, Property Rules, Liability Rules, and Inalienability: One View of the Cathedral, 85 HARv. L. REv. 1089 (1972). 
Dagan's "translation scheme" demonstrates how different measures of restitutionary recovery relate to control, well-being, or both. Assuming that the plaintiff was harmed less than the defendant was enriched - a presupposition Dagan makes in his paradigmatic case (p. 13) - measuring recovery as the plaintiff's harm encourages a savvy defendant to appropriate resources from plaintiffs who value them less than either the defendant or the market. In such a case, measuring restitution by the plaintiff's harm promotes sharing of resources by encouraging more efficient users to take without permission. Restoring the resource's fair market value protects the plaintiff's well-being by restoring her to her ex ante level of wealth, including her ability to sell the resource at market value. A recovery of net profits vindicates the plaintiff's control by removing a potential appropriator's economic incentive to take the plaintiff's resources, regardless of the defendant's higher valued use of those resources. Finally, a recovery of gross proceeds (not offset by the appropriator's expenses in using the resource) may be reserved for cases where a society wants not only to protect the plaintiff's control, but also to express its condemnation of the defendant's action. ${ }^{11}$

These four rationales motivate different levels of recovery and comprise the heart of Dagan's theory of valuation. ${ }^{12}$ "Choosing amongst these possibilities is not a purely theoretical enterprise; rather, it dictates and shapes the available remedies" (p. 15). The pattern of restitution that a national legal system offers - fair market value for certain resources, net profits for others, and so on is, Dagan claims, purposive, nonarbitrary, and subtly revealing of the contours of a national psyche.

\section{American Law Application}

In the American legal system, the law of unjust enrichment offers a menu of restitutionary remedies across a spectrum of resources (pp. 71-108). Within this single national setting, restitutionary awards can be explained by the extent to which they implicate the owner's "personhood." As Dagan writes:

11. It would be possible to construct a slightly different translation scheme in which "gross proceeds" were merely another but more effective method of protecting control. If, as Dagan claims, ex post recovery vindicates control by acting as an ex ante disincentive to appropriate (p. 15), then a higher level of recovery is just a more effective deterrent.

12. Dagan also introduces the concept of proportional profits whereby courts "reconstruct [] the way the parties would have divided the contractual surplus under circumstances of full information" (pp. 19-20). Proportional profits are a useful addition to the traditional Calabresi \& Melamed matrix, protecting something between the resource-holder's well-being and control. We omit this restitutionary remedy from our Figure 1 and from the remainder of our account because it does not substantially help us illuminate Dagan's theory or unravel our postsocialist application. 
[T] he sphere of control American law is expected to confer on its constituents will not be absolute, but rather will occur along a continuum of diminishing interests: from core interests (one's identity, physical integrity, reputation as dignity, and land) through lessprotected interests (copyright, and to a lesser degree, commercial attributes of one's personality and patents) to least-protected interests (contractual relations and performances and information). [p. 71]

In America, restitutionary recovery for core resources - such as for a trespass involving land - is often valued at the higher of fair market value or profits, thus vindicating what Dagan refers to as "well-being and control" (p. 75). In contrast, patents are protected from infringement only by an ex post award of fair market value (pp. 87-89). Dagan suggests that this lower level of protection shows that patents in America are less personal to their holder than certain rights in land may be. Therefore, if the infringer can make more beneficial use of the patent than the market price reflects, he or she may capture the excess gain and actually be encouraged to infringe. Figure 1 suggests the relationship Dagan is noting:

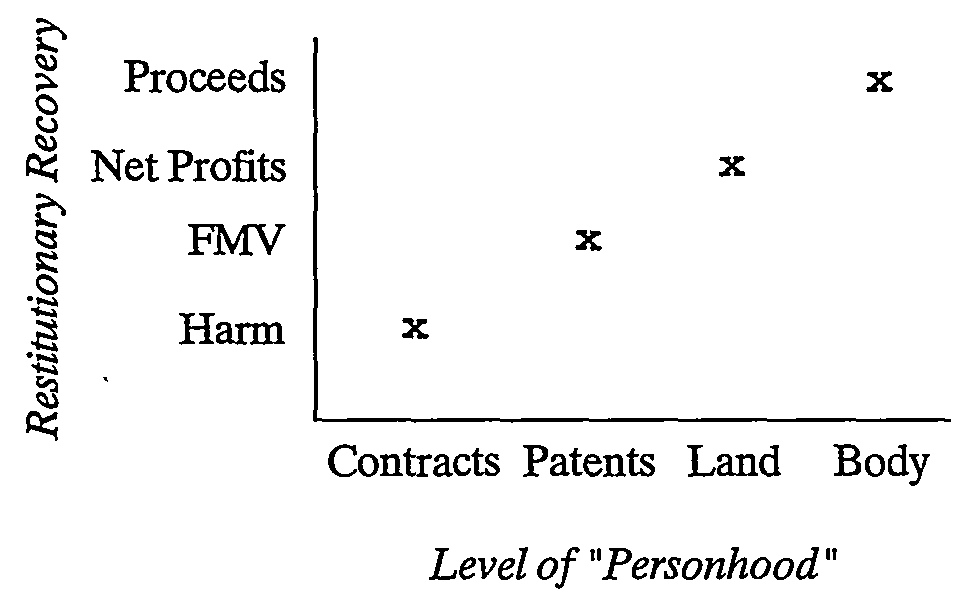

FIGURE 1: Explaining Variation in American Restitutionary Remedies

What seems to be arbitrary variation in the definition of gain to the defendant derives from intracultural values regarding personhood - a range of restitutionary values available within the American legal system (summarized in a second useful table, $\mathrm{p}$. 107). Dagan's exploration of Americans' relationship with various resources is astute, but raises some questions. Why does trespassing on land implicate personhood interests more than infringing on a patent? Perhaps the level of restitutionary recovery serves as an indicator of the "personhood quotient," so we learn from the restitutionary rules that Americans value patents less than land. Or the prediction could work the other way around: if we believe patents 
have lesser personhood quality, we should expect a lower measure of recovery for their infringement. Because, in fact, we see a lower recovery, his theory is confirmed. We are not sure which way the causation runs in what Dagan calls his "retrodictive" approach, which he defines as "the ability ... to predict prior events: here the details of the pertinent [restitutionary] doctrines" (p. 8). Dagan suggests a dynamic relationship between the social understanding of a resource and its legal protection. "Our attitudes towards one another and the prescriptions of our legal regime are embedded in one holistic web, each inculcating, and inculcated by, the other" (p. 39). The claim may be circular. ${ }^{13}$

The predictive (or, as Dagan would say, retrodictive) force of the argument also leaves out courts' frequent consideration of the defendant's good or bad faith behavior and numerous other moral and conventionally utilitarian concerns. For example, how courts value restitution often depends on whether the defendant was acting in good faith when he wrongly chopped the plaintiff's lumber. Dagan notes that courts will award gross proceeds if the defendant was acting in bad faith and the higher of fair market value and profits if the defendant's trespass was unintentional or innocent (p. 74). While this distinction reflects different rationales for recovery condemnation versus well-being and control - it is unclear to us why the defendant's motives should matter in Dagan's model, which asserts that the relevant variables are the national socioeconomic ethos and the character of the resource. An account could probably be developed to suggest why people in certain societies are more harmed by intentional rather than innocent appropriation. ${ }^{14} \mathrm{~A}$ given society may prefer to protect well-being if the trespass is unintentional but vindicate control for purposeful invasions. Dagan's account, however, does not explain why this distinction should be true and leaves us to ponder the ambiguous role of the defendant's bad faith in his model. ${ }^{15}$ Nevertheless, Dagan's

13. For example, we find Dagan's suggestion that patents are less personal than copyrights plausible but not obvious. As evidence for his claim, Dagan points to the different methods of valuing patent and copyright infringement (pp. 82-89). The argument, however, seems to assume what he is trying to prove: that methods of valuation correspond to the personhood quotient of various resources.

14. Cf. Michael A. Heller \& James E. Krier, Deterrence and Distribution in the Law of Takings, 112 HARv. L. REv. 997, 1007-09 (1999) (arguing that a per se takings rule for physical invasions - such as that suggested by Loretto v. Teleprompter Manhattan CATV Corp., 458 U.S. 419 (1982) - may lead to perverse results if government agencies respond by inflicting more costly, but nonphysical and hence noncompensable harms on property owners); Frank I. Michelman, Property, Utility, and Fairness: Comments on the Ethical Foundations of "Just Compensation" Law, 80 HARV. L. REv. 1165, 1227 (1967) (suggesting that "[a]ctual, physical use or occupation by the public of private property may make it seem rather specially likely that the owner is sustaining a distinctly disproportionate share of the cost of some social undertaking.").

15. The defendant's motives have long been a source of debate in the restitution scholarship. See John P. Dawson, The Self-Serving Intermeddler, 87 HARv. L. REv. 1409, 1410 
framework does analytic work explaining the otherwise odd variety of methods that courts use to value a-defendant's gain.

\section{Restitution and National Ethos}

Dagan's second argument is that legal systems are each characterized by a "socio-economic ethos" that varies along a scale of communitarian fellow-feeling. The book's final two chapters make this point by moving from an intra- to an intercultural analysis. In particular, Dagan switches to the quite distinct system of Talmudic civil law, parsing ancient religious texts to uncover the animating ethos of Jewish law. Given their different traditions, juxtaposing American and Talmudic law could be an odd choice if one system were intended to inform, or comment on the other. Dagan, however, uses the very heterogeneity of the systems he studies as a way to sharpen distinctions. ${ }^{16}$ For these purposes, Imperial Chinese law could have been equally apt as a comparison.

Dagan's approach seems straightforward. Various measures of recovery encourage different levels of appropriation or involuntary resource transfers: namely, restitution affects the amount of forced sharing. Cross-cultural variations in the measure of restitutionary recovery reflect differences in societies' communitarianism specifically, and social ethos generally. For example, with Americans, "one can expect that the rules of the American doctrine will be concentrated mainly between control and well-being. ... The American commitment to the individualistic values of desert and negative liberty is moderated by some - albeit fairly weak - egalitarian and needs-based convictions" (pp. 60-61). And indeed, the American legal system often measures restitutionary gain by the defendant's net profits; thus reducing incentives to appropriate by recapturing any possible gain from using a wrongfully taken resource. ${ }^{17}$

By contrast, in a more collective legal culture, people may sometimes permit appropriations when society gains overall. If a restitutionary award only restores the amount the original owner is harmed, then potential appropriators may take resources they can

(1974). Dagan's desire to address the issue is understandable but seemingly outside his analytic structure.

16. See p. 7 ("[C]omparative law is instrumental in establishing a 'liberating distance' from the dominant legal consciousness, thus uncovering the political and moral (often hidden) significance of legal doctrine. However, in order to be able to enjoy this important advantage, the comparativist should refer to legal systems that are set in environments which are culturally remote from our contemporary Western circumstances.").

17. Of course, people will still have an incentive to appropriate others' resources if their chance of being successfully sued is less than $100 \%$. Nevertheless, awarding net profits acts as a more significant ex ante deterrent for potential appropriators than awarding fair market value (assuming that the appropriator can put the resource to an unusually valuable use). 
better use and retain any difference between the harm inflicted and the gain received. Dagan characterizes such a culture as sharingoriented and offers Talmudic law as an example of this more communitarian ethos, noting that: "It seems safe to conjecture that the Judaic doctrinal rules are more of the sharing type" (p. 61). Across cultures, then, the tone or shape of restitution partakes of and in turn helps to constitute ingrained national values (p. 39).

This may in fact be the case, but the Talmudic case study Dagan provides is not entirely parallel to the American law examples. Dagan effectively uses the American system to demonstrate intracultural variation, but he does not provide comparable detail on the Talmudic law side. He focuses instead on a single (though apparently much-parsed) hypothetical: "[W]here the defendant derives a benefit and the plaintiff sustains no loss, for example where the premises of the plaintiff-landowner were not for hire (so that the harm was zero), and the defendant-squatter had no alternative accommodations" (p. 113). In such a case a Talmudic "exemption rule" applies, permitting the squatter-defendant to keep the amount he was enriched by the trespass. This outcome, Dagan claims, reflects the ethos of sharing embedded in the Talmudic law. The rule does not apply, however, the moment the plaintiff suffers some harm. Further exceptions to the "exemption rule" also limit its applicability so that the rule does not tell us much about the Talmudic ethic as a whole or give much footing for making an intercultural comparison. ${ }^{18}$

The "exemption rule" may indeed reflect a religious ethos concerned with sharing. It might be possible to generalize from this one example and explore how Talmudic civil law embodies a communitarian concern in other, unexpected cases. It might also be possible to demonstrate that the Talmudic law of restitution differs from the American law with regard to specific resources, perhaps from culturally different understandings of the relevant resource. Yet Dagan does not make the direct comparison, leaving the reader to infer the contrast between American and Talmudic law.

Dagan concludes with a look at international law, where he attempts to find a coherent ethos regarding compensation for governmental expropriation. ${ }^{19}$ We find this chapter the least persuasive because the issue of expropriation in international law remains a

18. Those further exceptions include cases where the plaintiff protests (pp. 120-21), where there is any positive enrichment to the defendant in the form of profits (pp. 121-24), and where the defendant is willing to pay (pp. 124-27). Dagan has, however, chosen an example that is central to Talmudic civil law.

19. As an aside, when an individual takes your resource without permission, we call it "appropriation"; when a government takes the resource, we term it "expropriation." 
source of conflict, not coherence. ${ }^{20}$ More generally, this material raises some questions about Dagan's method itself. He notes that the effort to identify a national "socio-economic ethos" cuts across "numerous different traditions" and "ideological conflicts" (p. 51), but he nevertheless claims to capture some generalized "essence" of specific societies and legal systems - American, Talmudic, and international. Can an ethos be so easily distilled? The stereotype that Americans value negative liberty is ubiquitous, but hard to pin down. Do Texans value negative liberty more than Michiganders? Conservatives more than liberals? The vast array of American values does not easily accommodate a single national ethos.

Our natural objection to being neatly categorized perhaps obscures some plausible truth to Dagan's claim. Americans may be more committed to negative liberty than people in some other countries. On the Talmudic side, it is hardly surprising to find a religious code concerned at some level with sharing, for one would expect to find the same in every other religion's ethical texts. But how does this aspirational document connect with the national ethos of contemporary Jews? Of Israelis? And, while it is improbable enough to discern a coherent ethos within a national or religious culture, we find ethos hunting even less credible at the international level.

A second difficulty with Dagan's presentation is how to tease apart the relationship between intracultural attitudes towards personhood and an intercultural ethos of sharing. For any particular resource, a difference in the restitutionary remedy between two legal systems is susceptible to either a resource-specific or national ethos explanation. Imagine, for example, that the American legal system has more control-oriented restitutionary remedies for unjust enrichment involving cars than the (updated) Talmudic response. This difference could equally result from an idiosyncratic attachment to cars in American culture as it could from a pervasive Talmudic emphasis on sharing transportation. Figure 2 suggests two ways in which the Talmudic system might differ from the American. Under the Sharing Interpretation, the Talmud places a systematically higher value on sharing and thus offers lower restitutionary remedies for each resource on the personhood continuum. By contrast, according to the Personhood Interpretation, the Talmud places different personhood weights on particular resources so that some resources receive more protection than in the American system, some less, some coincidentally the same. Dagan does not offer

20. See, e.g., Mark W. JANis, AN InTroduction to International Law $246-47$ (3d ed. 1999) (noting that whether there are "customary norms of international law providing international minimum standards that all states must meet regardless of treaty obligations is highly controversial, the positions of the Western states being much at odds with those of Third World nations"). 
a sufficiently parallel or detailed comparison to allow the reader to decide whether Talmudic law is systematically more sharingoriented, or whether it simply treats some particular resources as more invested in a person's essence than does the American system.

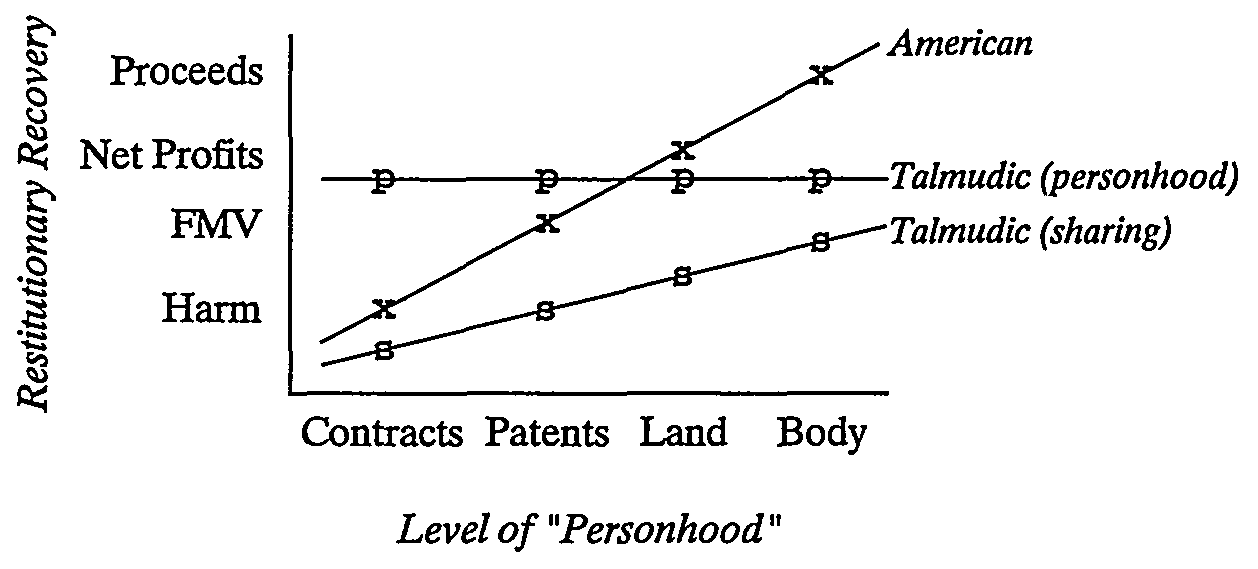

FIGURE 2: Untangling Personhood and Sharing in Intercultural Comparisons

This level of detailed comparison, however, goes beyond Dagan's project. He succeeds in his more important goal of revealing that restitutionary remedies may have a coherent structure explained by the intracultural factors and intercultural ethoses he identifies. Regardless of the precision of his comparisons, Dagan shows that methods of valuation can embody vastly different social values. His theory provides a theoretical context for thinking more systematically about the problem of valuation in law. Valuation of gain or harm, often dismissed as a merely technical matter, reflects normative principles at the core of a national legal ethos. Applied to the problem of restitution, Dagan's framework explains otherwise incongruous measures of recovery.

More generally, Dagan addresses the undertheorized link between concrete measures of valuation and abstract social values. If his approach succeeds, then it should be able to teach us something about new situations - such as the restitutionary practices in diverse transitions from socialist to market economies. Restitution is not only an interesting theoretical puzzle, as Dagan shows, but also a value-laden policy adventure in much of the world today. 


\section{Putting Restitution to the Test}

Restitution has been a core element of postsocialist transition, transferring the equivalent of billions of dollars in resources to prior owners. While the recent frenzy of restitution has been most extensive in Eastern Europe, new programs keep popping up elsewhere as well. ${ }^{21}$ The programs' forms are as numerous as the countries that are adopting them. The question we take up here is whether the diversity among restitution programs expresses something more than interesting curiosity or contingent political fact. Recent literature on restitution, mainly describing postsocialist transition in Eastern Europe, does not help solve the puzzle.22 Some commentators suggest that restitution reflects attempts by weak new governments to distinguish themselves from communist predecessors; others say that restitution may be an expedient way to shift resources to private ownership. Perhaps the programs represent simple power politics. Perhaps not. These accounts fail to make sense of the variety of restitutionary rules.

Dagan's method suggests a more useful way to think about restitution, going beyond dry technicalities to the guts of nationbuilding. ${ }^{23}$ Choices about who gets what back may help us discern core national attitudes towards important resources. Note, though, that just as Dagan's approach helps explain postsocialist restitution, real-world practice, in turn, challenges and refines Dagan's theory.

\section{A. The Relationship Between Privatization and Restitution}

Most of the time we acquire property through purchase or through some other method that accepts the prior owner's title as legitimate. When a country shifts away from socialism, however, this basic equation is disrupted and policymakers are cast out into an uncertain wilderness of first principles. State property, including

21. See supra note 5 (noting South African, Cuban, Native-American, and African-American cases).

22. See, e.g., Josef Burger, Politics of Restitution in Czechoslovakia, 26 E. EuRo. Q. 485 (1993); Anna Gelpern, The Laws and Politics of Reprivatization in East-Central Europe: $A$ Comparison, 14 U. PA. J. INTL. Bus. L. 315 (1993); Offe, supra note 7; Jeffrey J. Renzulli, Claims of U.S. Nationals Under the Restitution Laws of Czechoslovakia, 15 B.C. INTL. \& Comp. L. Rev. 165 (1992); Richard W. Crowder, Comment, Restitution in the Czech Republic: Problems and Prague-Nosis, 5 IND. INTL. \& CoMP. L. Rev. 237 (1994); Michael L. Neff, Comment, Eastern Europe's Policy of Restitution of Property in the 1990s, 10 Dick. J. INTL. L. 357 (1992); Heather M. Stack, Note, The "Colonization" of East Germany?: A Comparative Analysis of German Privatization, 46 Duke L.J. 1211 (1997); Frank Bönker \& Claus Offe, The Morality of Restitution: Considerations on Some Normative Questions Raised by the Transition to a Private Economy (June 18, 1993) (unpublished manuscript, on file with authors).

23. See also Gelpern, supra note 22, at 317 ("Extremely popular despite their uncertain economic significance, reprivatization initiatives offer insights into the nation-building agendas of the governments which preside over them."). Note that in the transition literature, the term "reprivatization" is synonymous with "restitution." 
nearly everything with economic value, is put up for grabs. And because people do grab, decisions about restitution programs must be made quickly before "spontaneous privatization" (a nice, postsocialist term for wholesale theft of state assets) renders the problem moot. ${ }^{24}$

Before defining a restitution program, a country must decide which resources to keep public - parks? railroads? streets? - and which to transfer to private ownership. They may transfer resources through a privatization program - giveaway vouchers? sales? auctions? - or through restitution. Each of these initial decisions is fraught with political meaning. Privatization of a factory by sale or auction partly legitimizes the prior socialist ownership of the factory, even as it practically makes funds available for the new reformist government. Giveaways of apartments to the current occupants imply that those occupants already rightfully own the apartments while recognizing their real need for a place to stay. Each mode of privatization carries its own verdict on the prior property regime. ${ }^{25}$

The relationship between restitution and privatization in postsocialist reforms is perhaps a useful one to note. Wherever it reaches, restitution denies the claims of current occupants or state owners. Restitution reknits a country with its distant past, excises the socialist period, and labels as unjust any intervening ownership. In Dagan's terms, the more that restitution prevails, the more it may reveal a national ethos committed to negative liberty; while privatization may suggest (in a surprising twist) a greater ethos of sharing.

Consider the ratio of privatization to restitution programs as one moves from west to east across Europe. While all the countries have privatized widely, the former East Germany also has a farreaching restitution program, the Central European countries have some restitution, and Russia has none. ${ }^{26}$ Consistent with Dagan's theory, the Russians lived the longest under a nominally sharingoriented socialist regime and they have the shallowest tradition of entrepreneurship (even before the Soviets, the Tsar's feudal system left little room for dispersed individual landownership). East Germany, conversely, retained a robust private property regime even under communist rule, maintaining a control-oriented concep-

24. See generally World Bank, World Development Report 1996: From Plan to MARKET 48-63 (1996) (outlining options for privatization and paths taken by postsocialist countries).

25. See Gelpern, supra note 22, at 315; Stack, supra note 22, at 1221 ("In theory, then, restitution sought to achieve a degree of parity between historic injustices and current economic needs.").

26. See generally Gelpern, supra note 22. 
tion of private property rights that perhaps finds new voice in the country's restitution laws.

\section{B. The Variety of Restitution}

Vindicating precommunist ownership through restitution raises diverse problems. Notice, however, how closely the situation parallels Dagan's basic paradigm but on a massive scale. Socialist rulers divested people of their property in forced transfers (now deemed unjust) to new owners whom the state believed could make more valuable use of the expropriated resources.

While restitutionary programs vary tremendously in their details, ${ }^{27}$ we group the variety along four main axes: ${ }^{28}$ (1) The types of lost resources that may be restituted - only real property? corporate stock? prison time? (2) The people who can benefit - only living citizens? exiles? corporations? religious communities? (3) The form that restitution takes - the land itself? roughly equivalent land? current or former fair market value? partial cash payment or voucher? ${ }^{29}$ And (4) the time period that restitution covers - excising only the socialist period? stretching back to cover Nazi expropriations of Jews and others?

Each point is fiercely contested, and each helps us to reflect on Dagan's project. Just as Dagan pares away the multitude of restitutionary paradigms to focus on a single case, we focus on a single contrast, between the Czech Republic and Hungary, to motivate our discussion. The former East Germany and Russia may work as well. So may Poland and Lithuania. Our pairing is open to a similar criticism as Dagan's paradigm - that a different choice may result in quite a different story. We offer the same defense as does he: we are only testing his method, not offering an exhaustive account of postsocialist restitution. With those disclaimers, we note that the Czech Republic and Hungary form a sufficiently complex comparison to start thinking about how national practice, national ethos, and attitudes towards property and personhood might interact in postsocialist transition.

\section{Restitution in the Czech Republic}

Restitution in the Czech Republic is one of the largest such programs in Eastern Europe. Favoring a policy of "natural" restitution (an interesting word choice as we shall see), the Czech government is restoring a still inestimable amount of property to its precom-

27. See id. at 315-16.

28. See id. at 323.

29. See Neff, supra note 22 , at 361. 
munist owners or their heirs. ${ }^{30}$ Truck drivers, shoe moguls, western bankers, human rights activists, elderly men and women with distant memories of expropriated properties, and heirs to ancient estates are among the many people repossessing property in the former Czechoslovakia (now separated into the Czech Republic, where we focus our attention, and Slovakia, which we do not examine). ${ }^{31}$ The Czech Republic's sweeping restitutionary program codifies normative policy decisions along each of the four axes that are controversial in Eastern European transition.

Three Czech laws together create a comprehensive program of restitution. ${ }^{32}$ All three laws codify a preference for "natural" restitution, which gives property back to its "original" owner. ${ }^{33}$ When the property's value increased significantly during communist possession, however, monetary compensation is sometimes awarded, equivalent to fair market value at the time of expropriation. ${ }^{34}$ This alternative is subject to strict monetary caps on the cash any single claimant may receive, the balance being paid in riskier state securities. ${ }^{35}$ For the most part, not surprisingly, most nonagricultural

30. See Gelpern, supra note 22, at 359-60 ("[R]emarkably few figures are available to gauge the cost of restitution in the Czech Republic."). The figure of $\$ 10$ billion is often quoted, but not verified. See id.

31. See, e.g., Janet Guyon, Noble Rot: As the Czechs Return Confiscated Property, Real Estate Languishes, WALl ST. J. EUROPE, May 6, 1993, at 1 (33-year-old banker in Monte Carlo, who had never been to Czechoslovakia, became a Czech prince through his father's restitution claims); Kitty McKinsey, Bata Shows You Can Go Home Again: 56 Years After Fleeing, Shoe King Is Inspiration in Land of His Birth, TORONTO STAR, Nov. 21, 1994, at D4; Marjorie Miller, Noble Try to Reclaim Heritage, L.A. TIMEs, July 3, 1994, at 1A (80-year-old Joseph Kinsky, who regained his castle after years working in communist uranium mines); Shailagh Murray, Real Estate: Prague Property Prices a Case for Kafka, Wall ST. J. Europe, Jan. 31, 1994, at 36; Hannah Rothschild, Coming Home, DaIly Telegraph, Mar. 12,1994 , at 38 ("[A family friend] lost everything in 1948. He went to live in a woodman's cottage and got a job driving trucks for a former employee. Last year, at the age of 74, he got his estates back. His boss was heard to say, 'I have lost my best driver but at least I've got my best landlord back.'").

32. The Small Restitution Law, enacted in 1989, restores private residences, small businesses, stores, and workshops expropriated between 1955 and 1959. See, e.g., Burger, supra note 22, at 486; Renzulli, supra note 22, at 178. The second law, the so-called Large Restitution Law, was enacted in 1991 and provides restitution for most other, larger property expropriated after 1948 and not covered by the Small Restitution Law. See, e.g., Burger, supra note 22, at 486; Gelpern, supra note 22, at 336. Finally, agricultural land is restored under a different regime codified by the Federal Land Law. Because agriculture was one of the few economic sectors to perform better than disastrously under communist rule, the Czech government was loath to disaggregate productive collective farms and threaten the nation's food production. See Burger, supra note 22, at 487.

33. See Crowder, supra note 22, at 239-40; see also Burger, supra note 22, at $485-86$ ("The concept of returning tangible real or personal property to rightful owners or their heirs seems at first sight simple enough. ... The lapse of forty years, after all, was not long enough to have erased memories of who had owned what. Nor were the public records, albeit modified by the Marxists, rendered useless for identifying lawful owners of properties as recorded before the ... 1948 coup.").

34. See Crowder, supra note 22, at 242.

35. See Gelpern, supra note 22, at 338. ("Cash compensation under the Large ... Restitution Law may not exceed ... about $\$ 1,000 ")$. 
property decreased in value during communism and "[m]any of the properties are returned in poor condition or beyond repair from years of neglect." 36 "

As with all restitutionary schemes in Eastern Europe, the Czech program met with substantial internal political resistance. Three principal objections were frequently voiced. First, the laws only cover property that was expropriated between the start of the communist regime in 1948 and its end in 1989 and thus exclude Jewish claims for property seized by the Nazis and claims by Sudeten Germans for property seized after the war by the Czechs. ${ }^{37}$ Second, the Czech program excludes foreigners and even Czech nationals living abroad from claiming restitution. ${ }^{38}$ This decision has generated controversy within expatriate Czech communities as it severely limits the scope of the restitutionary claims that might otherwise be available. ${ }^{39}$

Ultimately, however, the most salient objection is to the form of restitution; restoring property in kind comes with efficiency and distributional consequences. Many political actors argued for privatizing property instead by selling it to the highest bidder. ${ }^{40}$ Selling the resources would be relatively more likely to transfer assets to people motivated to use them effectively without muddying title. Privatization sale proceeds would simultaneously give the bankrupt new government resources to fund crucial programs - such as improving infrastructure and coping with emerging environmental disasters - or for making restitution. ${ }^{41}$

Nevertheless, restitution went forward on the massive scale originally contemplated. The complex implementation of Czech restitution has even taken priority over the slow process towards privatization. ${ }^{42}$ Commentators have alternatively charged natural restitution with both economic catastrophe ${ }^{43}$ and fiscal salvation for

36. Crowder, supra note 22, at 254; see also Neff, supra note 22, at 369.

37. See Stack, supra note 22, at 1242; Crowder, supra note 22, at 242-43; Robert Hochstein, Note, Jewish Property Restitution in the Czech Republic, 19 B.C. INTL. \& CoMP. L. Rev. 423, 423 (1997).

38. See Renzulli, supra note 22, at 178-81; Stack, supra note 22, at 1242-43. But see Neff, supra note 22, at 372 (arguing that the restriction may be less prohibitive than some Czech expatriates believe).

39. See Neff, supra note 22, at 372.

40. See id. at 370.

41. See Bönker \& Offe, supra note 22, at 48.

42. See Neff, supra note 22, at 370.

43. See, e.g., Gelpern, supra note 22, at 325-26 ("'Arguments that an extensive restitution of property in kind is the fastest form of privatization is [sic] a fiction. ... Instead of speeding up privatization, it would actually slow it down and prolong it perhaps for decades." (quoting BBC Summary of World Broadcasts, Feb. 15, 1991, available in LEXIS, World Library, BBCSWB File)); Crowder, supra note 22, at 252-56 (describing the "problems resulting from restitution in kind"). 
the Czech Republic. ${ }^{44}$ All, however, appear to agree that natural restitution signals a strong commitment to protecting private property. ${ }^{45}$ The Czech Republic's comprehensive program is often contrasted with Hungary's more limited restitutionary policies. ${ }^{46}$

\section{Restitution in Hungary}

Hungary took a substantially different path from the Czech Republic. Often described as "limited" compensation, Hungarian restitution provides no natural restitution but instead pays fixed rates for property taken by the communists. 47 The fixed values applied to property usually restore only a token percentage of the property's actual value. Claims up to $\$ 2,300$ are compensated in full; the next $\$ 1,150$ are compensated $50 \%$; the next $\$ 2,300$ get $30 \%$; and amounts above these totals get $10 \%$ up to a maximum compensation of about $\$ 57,000.48$

Hungarian restitution is not "limited" merely because of the undervaluation of restorable property. The form of the restitution, too, is more restricted than in the Czech Republic. Instead of cash, the Hungarian government pays original owners their compensation in state-created coupons. ${ }^{49}$ While these coupons are freely tradable securities, they are not fully liquid for five years and are intended to be used to repurchase state-owned property. ${ }^{50}$ The modest Hungarian goal is "partial indemnification, not reprivatization."51 Although early versions of the restitution laws allowed farmers to use their coupons to redeem their precommunist land holdings, the Hungarian Constitutional Court struck down this provision on the grounds that "it discriminated against former owners

44. See, e.g., Neff, supra note 22, at 369-70 (describing the economic success of Czech restitution resulting from its comprehensive protection of property ownership).

45. See Gelpern, supra note 22, at 318 (calling the Czech program "all-out restitution"); Neff, supra note 22, at 369.

46. See Gelpern, supra note 22, at 316; Bönker \& Offe, supra note 22, at 11-12.

47. See Gelpern, supra note 22, at 328 ("Hungary's limited compensation program reflects an atypical influence of the technocrats in its post-socialist politics ...."). Gelpern may overstate the significance of the political factors: initial restitution laws in Hungary provided for natural restitution.

48. See Gray et al., supra note 6 , at 309 ; see also Gelpern, supra note 22 , at 344 ; Neff, supra note 22, at 373-74. The scale incorporates a complicated set of valuation guidelines: "For non-agricultural real estate, compensation is measured in proportion to the area ... depending on the present location. Classifications include Budapest, provincial towns, villages and vacant lots outside any of the enumerated areas." Gelpern, supra note 22, at 344. Equally specific guidelines determine the restitutable value of corporations depending on the size of the workforce employed at the time of the expropriation. See id.

49. See Gelpern, supra note 22 , at 344-46.

50. See Neff, supra note 22, at 374.

51. Id. at 376. Again, "reprivatization" means "restitution" in the transition literature. 
of urban and industrial property, who were not given the possibility of natural restitution." 52

On the other hand, Hungarian restitution is broader than its Czech counterpart in two interesting respects: first, it reaches back to 1939 so it covers Nazi expropriations of Jews; and second, restitution can be granted to nonnationals and nonresidents. ${ }^{53}$ Given its other restrictions, these looser requirements may seem surprising. These factors have not, however, resulted in the anticipated flood of restitutionary claims. The Hungarian National Compensation Office, operating out of a former brothel, has needed to extend deadlines for filing claims several times for apparent lack of interest in the program. ${ }^{54}$ As of 1996, five years after Hungary's original restitution law was enacted, only seventy-five percent of restitution coupons had been issued, with a face value of approximately $\$ 650$ million.55 This is dramatically less than the two to four billion dollar price tag originally anticipated. ${ }^{56}$ Hungary's restitution has proceeded on a much smaller scale than its Czech neighbors' program.

\section{Gaps in the Existing Literature \\ 1. Why Restitute Property At All?}

Facing substantial political opposition, the Czech Republic and Hungary nevertheless persevered with restitutionary programs. The short-term economic cost of restitution has been high, hardly a surprise. In particular, natural restitution overburdens weak new legal institutions because of problems associated with unclear title, the condition of the property being returned, and the creation of numerous wrenching conflicts between current and former owners. ${ }^{57}$ Even the Hungarian program creates a substantial legal and administrative headache. The best reasoning counsels against restitution at all. As Jon Elster has written:

It is important to keep in mind that essentially everybody suffered under Communism. Whereas some lost their property, others many others - had opportunities denied to them through the arbitrary or tyrannical behavior of the authorities. ... It would be arbi-

52. See Gray et al., supra note 6, at 309 n.111; see also Peter Paczolay, Judicial Review of the Compensation Law in Hungary, 13 MrCH. J. INTL. L. 806, 813-17 (1992); Bönker \& Offe, supra note 22, at 34 ("It took three decisions of the Hungarian Constitutional Court to limit the preferential treatment for land. According to the first draft of the ... law, expropriated land would have been given back, whereas other kinds of confiscated property would have been only compensated.").

53. See Gelpern, supra note 22 , at $343,347$.

54. See id. at $348,363$.

55. See European Bank for Reconstruction \& Development, Transition Report 6 (Nov. 3, 1997), available in Westlaw, 1997 WL 18308670.

56. See Gelpern, supra note 22, at 363.

57. See Crowder, supra note 22, at 249-57. 
trary and wrong to single out one group of victims - the owners of tangible property - for compensation.... Property rights are, in my opinion, among the least rather than most inviolable rights. Those protecting individual dignity, autonomy, and privacy are much more central. ... Full compensation to some of the victims cannot be defended as a second-best approximation to the ideal of universal compensation, if that ideal itself is meaningless. 58

Given these arguments, why restitution? Some commentators have suggested that long-term economic gains may offset any current economic slowdown. ${ }^{59}$ Restitution is undoubtedly a "technique to build a private economy,"60 at least in part. It may serve as a signaling mechanism to Western investors that their investments will be protected - "restitution enhances the credibility of economic reform by demonstrating the government's belief in the virtues of private property."61 Also, it transfers resources to former owners who may then trade them to more productive users than socialist owners. The complexity of large-scale restitution, however, weakens the efficiency point just as Elster's arguments undermine justice claims. In the Czech case, the commitment to natural restitution is perplexing. Full monetary recovery is as strong a signaling mechanism, but it would permit the current government to sell land to the highest bidder and create clear title.62

Economic policy can perhaps help explain Hungary's more limited program of restitution. The country began transition with a heavy debt load and, perhaps, could not afford to restore as much as its neighbors. ${ }^{63}$ Why, though, if fiscal constraints were of such concern, would Hungary have expanded the group of people eligible for restitution to include foreigners? Perhaps Hungary made a sophisticated decision to adopt a modest program for all, while the Czechs decided on more comprehensive restitution for native Czechs alone. But this distinction only begs the question of why a

58. Jon Elster, On Doing What One Can: An Argument Against Post-Communist Restitution and Retribution, E. Eur. CoNST. REv., Summer 1992, at 15, 16-17. Other commentators have explored restitution through the lens of moral duty. See Offe, supra note 7 , at 43 (" $[T]$ he moral objection may be raised that it is unfair that, within the universe of victims of the old regime, the subset of expropriated owners of productive assets alone can [claim restitution]."). After analyzing the legitimacy of the original expropriations according to both deontological and consequentialist standards, Bönker and Offe conclude that moral arguments cannot justify restitution. See Bönker \& Offe, supra note 22, at 47.

59. See Crowder, supra note 22 , at 262 ("[P]roviding the Czechs with some sense of justice for the egregious wrongs committed by the communists appears to be a necessary step to growing the cause of democracy and economic reform. Not taking this step might have resulted in a much worse long range outcome for the Czechs.").

60. Bönker \& Offe, supra note 22 , at 11.

61. Id. at 21; see also Crowder, supra note 22, at 240, 250.

62. See Crowder, supra note 22, at 257-58 (objecting to natural restitution because of its inefficiency).

63. See Gelpern, supra note 22, at 330. 
country would prefer one approach to another. The difference between the Hungarian and Czech programs reflects more than the depth of their respective pockets. Both were broke. While economic interests must surely be motivating some of the choices in the restitutionary movement, they cannot provide a fully satisfying story and do not adequately explain restitution's various contours across resources, even in the two neighboring countries we are considering.

\section{Why Natural Restitution?}

Full restitution of economic value seems unlikely enough, but returning specific plots of land to their owners from half a century ago seems incredible. Two plausible justifications have been given for natural restitution. In the first days of transition, only discredited former communists had sufficient resources to purchase property sold on the market. Natural restitution was an expensive attempt to keep the property out of their hands (and even more crucially for the Czechs, a way to keep property away from potential German buyers). ${ }^{64}$ Natural restitution, however, may not have been up to this task. Because of the level of disrepair of most real property, many entitled owners refused to file restitutionary claims. The result has sometimes been the transfer of vast quantities of land to outsiders - the only people who can afford to maintain the property. ${ }^{65}$ Natural restitution may be largely motivated by a desire to keep property out of ex-communist and German hands, but its effects are conflicting at best and counterproductive at worst.

Natural restitution remains intuitively appealing in a manner not captured by economic concerns - putting an elderly widow (or more likely, her heirs) back in her childhood apartment, the one she has longingly walked by for five decades. Somehow, then, restitution participates in a moment of personal and cultural definition. When a country signals its change to a new regime, it sends a message to its own citizens, at least as much as to foreign investors. Yes, restoring property indicates a renewed commitment to private ownership, but it also distinguishes the new regime's commitments from its communist predecessors' illegitimacy.

64. See It Still Hurts, The Economist, May 21, 1994, at 58 (noting that Vaclav Havel, the Czech President, was "adamantly opposed to compensation" for the 2.5 million Sudeten Germans expelled at the end of WWII); see also Offe, supra note 7, at 42 n.59.

65. See Crowder, supra note 22, at 254-55. "George Lobkowicz, a European banker who had never been to Czechoslovakia, recently became a Czech prince, and his family became one of the country's biggest landowners as a result of the restitution laws." Id. at 255. 
Restitution has sometimes been cast in terms of "national rebirth and "moral purification," "66 an attitude that may explain the preference for natural citizens and the precision with which governments choose the dates for restorable expropriations. Limiting the class of people eligible to claim restitution helps create a mythical cultural identity; it serves as a tacit statement about who counts as "real" Czechs or Hungarians in these newly emerging states. ${ }^{67}$ Shlomo Avineri noticed that most former socialist countries, including the Czech Republic, chose cut off dates for restitution that coincided with the most ethnically pure moment in the country's history. ${ }^{68}$ In the Czech case, this was just after the Nazis had murdered the centuries-old Jewish community, and the Czechs had brutally expelled an equally rooted German community. ${ }^{69}$ Similarly, the Lithuanians chose the moment when the Jews and the Poles had been murdered and kicked out; 70 the Poles when the Jews, Germans, and Russians were gone; ${ }^{71}$ and so on. Restitution, then, serves as part of national myth making, linking people to an imagined (or hoped for), ethnically pure past; that is, linking today's citizens to the "natural" owners of national private property.

Avineri's understanding of restitution leads us nicely into Dagan's framework. What myth is a country creating or evidencing through its restitutionary scheme? If restitution does not result only from contingent political and economic facts, ${ }^{72}$ then Dagan's theory suggests that each country's program may embody important - and importantly different - socioeconomic characteristics. Identifying these differences opens another level of subtlety through which to understand postsocialist societies.

66. Gelpern, supra note 22, at 323 (borrowing terminology from Vratislav Pechota, Privatization and Foreign Investment in Czechoslovakia: The Legal Dimension, 24 VAND. J. TRANSNATL. L. 305, 308 (1991)).

67. See Gelpern, supra note 22, at 356 ("All of the reprivatization initiatives generally bypass or subordinate the claims of ethnic minorities, most of which had been expropriated in succession prior to the relevant cut-off dates ....").

68. Shlomo Avineri, Lecture at the Conference on Restitution in Eastern Europe, Central European University, Budapest, Hungary (June 18-19, 1993).

69. See Stephen A. Denburg, Note, Reclaiming Their Past: A Survey of Jewish Efforts to Restitute European Property, 18 B.C. THIRD WORLD L.J. 233, $256-57$ (1998).

70. See William Valletta, The Hesitant Privatization of Lithuanian Land, 18 FordHAM INTL. L.J. 198, 203-04 (1994) (limiting restitution to current citizens willing to farm the land).

71. See William R. Youngblood, Note, Poland's Struggle for a Restitution Policy in the 1990s, 9 EMORY INTL. L. REv. 645, 646 (1995).

72. For example, we are assuming that Hungary's limited restitutionary program was a result of more than the poor showing of its prorestitution party at the polls. See Offe, supra note 7, at 26-27; Gelpern, supra note 22, at 318 (arguing that "the likelihood of passing strong restitution measures varies inversely with the strength of the left and the technocrats in the political arena" which in turn depends on "the manner of each country's transition from state socialism."). There should be an interesting story to tell beyond these political accidents. 


\section{Postsocialist Restitution Through the Dagan Prism}

What can Dagan's approach tell us about the Czechs and Hungarians? And what do their experiences tell us about his theory? Dagan's framework suggests we look for messages hidden in postsocialist restitution programs. Interpreting these messages requires some work. The remainder of this review is a tentative first step.

\section{Of Control and Well-Being}

First, consider natural restitution. To the Czechs, it may signal condemnation of certain expropriations and a commitment to particular victims of communism; to outsiders, it may signal a better investment climate with renewed respect for private property. ${ }^{73} \mathrm{In}$ tuitively, natural restitution seems like a strong commitment to individual liberty and a rejection of sharing through forced transfers. It appears to stand in sharp contrast to Hungary's limited compensation. This preliminary conclusion may be too simple, however. In Dagan's hierarchy of restitutionary values, return of the rundown original property does not vindicate either the original owner's control or her well-being. What is going on?

According to Dagan's translation scheme, restitutionary remedies that vindicate control do so by removing a potential expropriator's ex ante incentives to take property unjustly. Natural restitution fails this test. According to the Czech program, communist expropriators return property only when it makes them no worse off than before the taking. In the rare cases when the communists increased the property's value, the original owner does not benefit. ${ }^{74}$ Dagan would term the unusual rationale motivating this system "well-being or control"; it permits recovery of only the lesser of fair market value and profits and is rarely used. Dagan notes,

[T] he well-being or control rationale reverses forced transfers only in so far as the remedy does not diminish the defendant's ex ante level of welfare. This creates an incentive effect of encouraging forced transfers .... [which] not only encourages efficient transfers, but encourages all transfers indiscriminately. This may be the reason why the well-being or control rationale is not evident in any case or statute covered by this book. It can thus be safely omitted from our translation scheme. [p. 21]

73. See Bönker \& Offe, supra note 22 , at 21.

74. See Neff, supra note 22 , at 369 (describing the Czech law that requires original owners of the rare property that has increased in value to remit the difference to the expropriator). The Large Restitution Law, however, may be ambiguous in its treatment of property that has increased in value. The relevant baseline may be the date when the Law went into effect and not the date of the original expropriation. Under this interpretation, the original owner is only responsible for compensating increases in value since 1991 when the Large Restitution Law was enacted. See Gelpern, supra note 22, at 338 n.81. 
Dagan omits the rationale too quickly. Maybe it is missing from stable market economies, but Czechs, among others, have chosen this as their focus for restitution. Natural restitution sends a message: not of the vindication of personhood through protection of property, but nearly the opposite, that the communists could gamble with your land and then, when they lost, return it to you in shambles. In the Czech Republic, the property returned is often more of a liability than an asset, property the state willingly gives back. ${ }^{75}$

By offering a percentage of the property's fair market value up to a fixed ceiling, Hungary also adopts an ex post level of recovery that reinforces the ex ante incentive to expropriate. Hungary's system is based on the rationale of well-being. It aims to restore the original owner to some fixed percentage of her ex ante level of wealth. While this is not precisely a valuation scheme that Dagan considers, the remedy suggests to future expropriators that they have little to fear from this method of restitution. Expropriators have effectively been granted an entitlement to use the property, while being called on to restitute only a fixed and minimal percentage of its actual value. The Hungarian system, however, includes the following caveat: the fair market value of property valued at less than $\$ 2,300$ is restored in full. For smaller property, then, Hungary's purportedly limited restitution is even stronger than Czech natural restitution; in Hungary, people's well-being is fully vindicated with respect to their smaller and perhaps more personal assets. This is indeed a surprising result.

Viewed in Dagan's terms, the Czech and Hungarian transition programs no longer seem to fall on opposite sides of the restitutionary spectrum. Both countries are enacting limited property protection that may reinforce the perverse incentive to expropriate. The sharpest contrast in restitutionary approaches, then, is not between natural and monetary restitution. ${ }^{76}$ Rather, both programs stand together in contradistinction to other programs, such as that enacted in the former East Germany, in which the government restores either the property itself or its current fair market value,

75. See Crowder, supra note 22 , at 254 . The property is not returned free and clear. Already dilapidated buildings may have tenants who cannot be evicted and for whom basic services must continue to be provided. "Protective rent controls place owners in a precarious situation by not allowing rent increases to keep pace with maintenance costs." Id. at 256.

76. This, despite commentators' implicit assumptions to the contrary. See, e.g., Gelpern, supra note 22, at 316 ("At the other end of the spectrum [from the Czech Republic], Hungary has granted former owners near-nominal compensation in capital vouchers."); Youngblood, supra note 71, at 645 ("[Restitutionary programs] range from no restitution to the return of all property taken by the former government."); Bönker \& Offe, supra note 22, at 11-12. 
whichever the original owner prefers. ${ }^{77}$ Germany's "well-being and control" remedy - also applied to the most protected resources in American restitution law - removes ex ante incentives for future expropriators to take property unjustly by restoring the greater of fair market value and profits. The Czech Republic and Hungary provide no such disincentive.

Dagan's approach has already provided a powerful and counterintuitive insight: rules valuing restitution may reveal normative positions even more clearly than do rules on the physical form of recovery.

\section{Eastern Europe and the "Personhood" of Property}

What does the general decision to vindicate well-being or control tell us about underlying social values? Here, Dagan's framework is indeterminate but still useful. The Czech and Hungarian laws may be able tell a story about their relationships with particular restituted resources, or they may equally well reflect each country's socioeconomic ethos.

Within the Czech Republic, restitution's political success was tied to the personal significance of the resource at issue. For example, passage of the Small Restitution Law can be explained, in part, because the law "returned small property of greater personal significance to a larger number of people than did the subsequent laws."78 As Czech policy moved away from core resources, opposition increased. Even within a general framework of limited natural restitution, the Czechs created a hierarchy similar to the one Dagan reports in the American legal context. While the restitutionary remedy does not vary across resources in the Czech Republic natural restitution is exclusively favored - differing political reactions to the various stages of restitution strengthen Dagan's claim that the rules reflect a people's relationship to different resources.

Looking to the personhood quotient of a resource opens a new way of perceiving Hungarian restitution. Instead of a mere economic necessity, Hungarians' sliding scale grants greater protection to items of smaller economic value but perhaps more personal meaning. By giving full fair market value for smaller losses, the Hungarians vindicate the most acute interests people had, not in great concentrations of wealth, but in ordinary things like the family apartment. Dagan's framework helps explain, and perhaps justify, Hungary's approach.

77. See Rainer Frank, Privatization in Eastern Germany: A Comprehensive Study, 27 VAND. J. TRANSNATL. L. 809, 833 (1994). This principle is subject to several important exceptions that limit natural restitution. See id. at 833-38.

78. Gelpern, supra note 22, at 327. 


\section{The Ethos of Expropriation}

The personhood quotient of a resource is only one side of Dagan's analytical coin. Flipping now to the other, each country's social ethos may also make its respective restitutionary programs more intelligible. The restitutionary rules reflect how people today understand the legitimacy of the original expropriation. Countries that judge the communists more harshly now may place more emphasis on higher restitutionary awards, to the extent they can afford them. ${ }^{79}$ Both the Czechs and the Hungarians suffered communist rule and Soviet invasion, and today both go to considerable lengths to distinguish themselves from their political predecessors.

A generation of communist rule could have plausibly affected each country's sharing ethos - an ethos shift that may be reflected in its restitutionary awards. ${ }^{80}$ Dagan does not explore this issue in his case studies; rather, he takes the ethos as a given, an exogenous rather than endogenous variable in restitution programs. Contrast, for example, East Germany's socialist regime, "where small business presence was tolerated in manufacturing and service sectors, [with] the Czechoslovakian Communist government [that] nationalized practically all business to the state or operated these business in the form of cooperatives." 81 Did more intensive socialist rules shift attitudes so that people became less invested in particular material resources?

The original Czech expropriation was on an enormous scale: "since 1945, the Czech lands had undergone the largest-scale nationalization in the region." 82 Whether this reflected a preexisting national view of sharing or marked a radical shift, communal ownership was ubiquitous by the time the communist regime fell. The Czech's aggressive attack on private property perhaps created - or did it reflect? - a willingness to permit forced transfers of resources. In turn, perhaps this willingness can begin to explain why Czech restitution protects only well-being or control, while East Germany protects well-being and control. In other words, the form of restitution may teach us that Czechs had more tolerance for com-

79. See Gelpern, supra note 22, at 330 ("[T] he extent of compensation can be only as great as the country's load-bearing capacity permits." (quoting speech by Imre Konya, parliamentary leader for the Hungarian Democratic Forum, Political Parties in Brief, BBC Summary of World Broadcasts, Feb. 20, 1992, available in LEXIS, World Library, BBCSWB File)).

80. The communist government in Czechoslovakia engaged in systematic efforts to eradicate almost all forms of private ownership. For over 40 years, then, Czech citizens were indoctrinated into communal ownership and the government's right to collectivize people's land and expropriate their property. See Renzulli, supra note 22, at 170-74.

81. Neff, supra note 22, at 370.

82. Gelpern, supra note 22, at 324-25; see also Crowder, supra note 22, at 240 ("You can't understand the scope of the challenge ... until you realize that here we don't own anything other than our toothbrushes."). 
munist nationalization than did the Germans, whose restitution programs reflect more complete rejection of communist nationalization. Or maybe East Germans just had richer patrons - Dagan's theory is not really designed to help us distinguish these cases.

The cutoff dates for restitution may also give some insight into national ethoses, beyond the symbolic myth-making role we have already discussed. ${ }^{83}$ Immediately after World War II, the Soviets expropriated land in East Germany that is not being restituted now. This results partly from the deal the Soviets made when they left Germany in 1989, but also from a sense of the legitimacy of the initial Soviet actions punishing the Nazis and breaking up feudal estates of the discredited Junker class. ${ }^{84}$ Similarly, in the Czech Republic, "[t]he intensity and breadth of opposition to the Czech Restitution Law [with an earlier recovery date] is evidence of popular belief in the justice of these post-war expropriations, and the persistent assumption of the collective guilt of Germans." 85 The perceived legitimacy of the original expropriation affected the restitution debate. ${ }^{86}$ Dagan's approach focuses on a national ethos of sharing versus individualism, but the postsocialist experience shows that this variable is itself responsive to historical events.

More bluntly, people seem more sharing-oriented when their government is sharing around a disfavored group's property. In other words, when designing restitution laws people ask (and commentators should ponder): sharing with whom? It is not only the quantum of personhood invested in a resource that matters, but whose resource is at stake. Perhaps a restitution program reflects the innocuous judgment that heirs and distant generations have less personhood wrapped up in a piece of property than living and present citizens. More invidiously, the idea of sharing can be used to exclude disfavored groups from claiming restitution.

Recognizing that sharing orientation depends in part on the social status of the original owner also explains limitations on who can file restitutionary claims. Why exclude Czech citizens living abroad? Why not permit foreigners to recover property? The simple answer is that the Czech Republic has come to view their precommunist expropriations as relatively legitimate, by contrast with Hungary, which has not.

83. See supra section III.C.2.

84. See Crowder, supra note 22, at 243; Stack, supra note 22, at 1221-22.

85. Gelpern, supra note 22, at 327-28.

86. See, e.g., Youngblood, supra note 71, at 646 (discussing Poland's proposed restitutionary plan which distinguishes between property taken by the Polish government and property taken by the Communists, claiming that "the latter is merely a cost of war," and distinguishing between property taken pursuant to communist law and property taken outside the law.). 
We find ourselves surprised to describe the Czech Republic, with its nationalistic, natural restitution approach, as perhaps more sharing-oriented than Hungary with its limited cash vouchers. The details of the programs, though, help qualify our understanding of each national ethos. Compared with the Czechs, the Hungarians evidence a relatively stronger individualist ethos by reaching back to 1939 and they demonstrate a less nationalistic version of the sharing ethos by restituting limited resources to a wide community. The ethos of sharing, which seems to have a warm and fuzzy aspect in Dagan's Talmudic story, reveals a nationalistic and exclusive undertone when run through the Eastern European example.

Thinking about the Czechs sent us back to our Talmudic sources (rather, we cadged advice from those who know). Apparently, the Talmud would not distinguish in Dagan's core example between the Jewish and Gentile squatter; neither would owe restitution to the landowner. Elsewhere, however, Talmudic law differentiates sharply the obligations Jews owe to each other and to non-Jews. ${ }^{87}$ The Talmud may require sharing within the group, but not with outsiders. In the Talmud, as in Eastern Europe, attitudes toward sharing turn out to be complex and contextual, dependent as much on the definition of community as on the personhood of resources.

\section{CONCLUSION}

Dagan offers a useful new tool for thinking about comparative law. Rather than losing ourselves in technicalities, an occupational hazard that drives comparative scholars to abandon the field, Dagan shows how we can extract the social values embedded in the private law. Using his method, we can parse the core social values hidden in any area of law. The technicalities of unjust enrichment reveal compelling stories about property, personhood, and national ethos. When put to a practical test, Dagan's approach opens a window on the frenzy of restitution across the former socialist world, an issue of practical and political significance that has received almost no theoretical attention. Dagan provides the intellectual tools we need to start the job.

87. See, e.g., Steven D. Fraade, Navigating the Anomalous: Non-Jews at the Intersection of Early Rabbinic Law and Narrative, in THE OTHER IN JEWISH ThOUGHT AND HISTORY 145, 147-58 (Laurence J. Silberstein \& Robert L. Cohn eds., 1994). For example, Fraade analyzes a passage from the Mishnah which discusses the remedy for one ox goring another ox. If both oxen belonged to Jews, the live one was to be sold and its profits divided between both owners - a sharing rule. However, if a non-Jew's ox was gored, no compensation was due, and if the ox of a non-Jew gored the ox of a Jew, full compensation had to be paid - a damages rule imposed against outsiders. Id. at 147. Though Talmudic interpretations of obligations owed to non-Jews have evolved since medieval times, disparate treatment continues to trouble interpreters. See generally JACOB Katz, Exclusiveness and Tolerance (1961) (examining the complex and reciprocal evolution of Jewish and Gentile attitudes toward each other); David Novak, Jewish-Christian Dialogue 26 (1989) (emphasizing the Noahide Laws which form "the rubric for the formulation of Jewish views of non-Jews"). 


\title{
THE RICHNESS OF CONTRACT THEORY
}

\author{
Randy E. Barnett*
}

The Richness of Contract Law: An Analysis and Critique of Contemporary Theories of Contract Law. By Robert $A$. Hillman. Boston: Kluwer Academic Publishers. 1997. Pp. xiv, 279. $\$ 120.50$.

\section{Introduction: The Generational Shift in CONTRACTS SCHOLARSHIP}

When I teach the doctrine of good faith performance, I assign an exchange between two distinguished contracts scholars, Robert Summers and Steven Burton, that has come to be known as the "Summers-Burton" debate. ${ }^{1}$ This debate is interesting not only for the contrasting views of its protagonists concerning the doctrine of good faith, but also because of the generational shift in modes of scholarship it represents.

In the 1950 s and 1960 s, contracts scholars, like so many others, rejected so-called "conceptualist" or "formalist" approaches that attempted to dictate the outcome of cases with general concepts and rules. Contracts scholarship was dominated by supposedly "realist" inquiries into the complexities of actual commercial practice, inquiries which sought to identify the multiple factors or considerations that judges do or should take into account when deciding cases. Usually it was denied that these factors could or should be weighted or organized in some manner in advance of a legal dispute. Any effort to reduce the vast complexity of the real world of commercial practice to some verbal formula was dismissed as "reductionist" or "simplistic."

The Oxford English Dictionary defines "reductionist" as: "An advocate of reductionism; one who attempts to analyse or account for a complex theory or phenomenon by reduction." 2 And it defines "simplistic" as: "Of the nature of, or characterized by, (extreme) simplicity. Now usu[ally] with the connotation of excessive or misleading simplification."3 An 1881 example of the word's usage captures the "realist" spirit that eventually captured the imagi-

* Austin B. Fletcher Professor, Boston University School of Law. B.A. 1974, Northwestern; J.D. 1977, Harvard. rbarnett@bu.edu - Ed.

1. See Randy E. Barnett, Perspectives on Contract Law 250-67 (1995).

2. 13 OXford ENGlish Dictionary 437 (2d ed. 1989).

3. $15 \mathrm{id}$. at 501. 
nation of legal scholars: "The facts of nature and of life are more apt to be complex than simple. Simplistic theories are generally one-sided and partial." 4

Professor Summers is of the generation of legal academics that was taught by the vanguard of "realist" professors - a generation that took their teachers' gestalt and terminology to heart. For example, to explain the implied duty of good faith performance in his seminal 1968 article, "Good Faith" in General Contract Law and the Sales Provisions of the Uniform Commercial Code, ${ }^{5}$ Summers proposed a series of six categories of bad faith performance: (a) evasion of the spirit of the deal, (b) lack of diligence and slacking off, (c) willfully rendering only "substantial performance," (d) abuse of a power to specify contract terms, (e) abuse of a power to determine compliance, and (f) interfering with or failing to cooperate in the other party's performance. ${ }^{6}$ In terms that embody the spirit of the realist generation (and of those whom the realists taught), Summers explicitly denied that any more general conception of good faith was helpful or even possible:

It is submitted that any but the most vacuous general definition of good faith will ... fail to cover all the many and varied specific meanings that it is possible to assign to the phrase in light of the many and varied forms of bad faith recognized in the cases. ...

... [G]eneral definitions of good faith either spiral into the Charybdis of vacuous generality or collide with the Scylla of restrictive specificity. ${ }^{7}$

A judge, he advised, "should not waste effort formulating his own reductionist definitions. Instead, he should characterize with care the particular forms of bad faith he chooses to rule out ...."8

In the 1970s and 1980s, this attitude toward scholarship began to change. Legal scholarship shifted away from realist modes toward what came to be called "legal theory." Contracts scholarship, like other fields, came to be dominated by scholars who risked the epithets of "reductionist" and "simplistic" in search of unifying theories of legal doctrine. For reasons I have elaborated elsewhere, ${ }^{9} \mathrm{I}$ attribute this generational shift initially to the rise of law and economics - which directly responded to the consequentialist or "pol-

4. Id.

5. Robert S. Summers, "Good Faith" in General Contract Law and the Sales Provisions of the Uniform Commercial Code, 54 VA. L. REv. 195 (1968).

6. See id. at 232-43. In this same article, Summers also provides five circumstances indicating "bad faith in the negotiation and formation of contracts," $i d$. at 220-32, three instances involving "bad faith in raising and resolving contract disputes," id. at 243-48, and four forms of "bad faith in taking remedial action," $i d$. at 248-52.

7. Id. at 206.

8. Id. at 207.

9. See Randy E. Barnett, Contract Scholarship and the Reemergence of Legal Philosophy, 97 HARV. L. REv. 1223 (1984) (book review). 
icy" concerns of the realists - and to the subsequent emergence of normative legal philosophy that sought to trump the "conservative" conclusions of efficiency theorists that many "progressive" legal scholars found unpalatable. As a result, scholarship like Robert Summers's realist lists of multiple factors that judges, in their discretion, needed to take "into account," began to give way to more systematic theories and approaches.

One of these was a comprehensive theory of good faith performance developed by Steven Burton, which he presented in his 1980 article, Breach of Contract and the Common Law Duty to Perform in Good Faith. ${ }^{10}$ According to Burton, the problem of good faith performance arises when a contract gives one party a degree of discretion in performing, and this discretion is then used by that party to recapture an opportunity foregone at contract formation. So to determine whether a party has acted in bad faith, one must identify both an opportunity objectively foregone and a subjective intention to recapture it.

Burton contended that without "an operational standard that distinguishes good faith performance from bad faith performance,"11 the general requirement of good faith as contained in the Uniform Commercial Code "appears as a license for the exercise of judicial or juror intuition, and presumably results in unpredictable and inconsistent applications."12 And he specifically took issue with Summers's "list of factors" approach: "No effort is made to develop a unifying theory that explains what these categories have in common. Indeed, the assertion is made that one cannot or should not do so."13 In contrast, Burton argued that "[r]epeated common law adjudication, however, has enriched the concept of good faith performance so that an operational standard now can be articulated and evaluated." 14 Burton's theory was based on "a survey of over 400 cases in which courts explicitly refer to good faith in performance," 15 but also on a basic low-tech efficiency analysis. ${ }^{16}$

Summers did not remain silent in the face of this challenge, and his response was methodological as much as it was substantive:

My view is that all such efforts to define good faith, for purposes of a section like 205, are misguided. Such formulations provide little, if

10. Steven J. Burton, Breach of Contract and the Common Law Duty to Perform in Good Faith, 94 HARv. L. REv. 369 (1980) [hereinafter Burton, Breach of Contract]; see also Steven J. Burton, Good Faith Performance of a Contract Within Article 2 of the Uniform Commercial Code, 67 Iowa L. Rev. 1 (1981).

11. Burton, Breach of Contract, supra note 10, at 369.

12. Id. at 369-70 (footnote omitted).

13. Id. at 369 n.5.

14. Id. at 370 (footnote omitted).

15. Id. at $380 \mathrm{n} .45$.

16. See id. at $392-94$. 
any, genuine definitional guidance. Moreover, some of them may restrictively distort the scope of the general requirement of good faith. . . . Finally, the very idea of good faith, if I am right, is simply not the kind of idea that is susceptible of such a definitional approach. ${ }^{17}$

Substantively, he argued that Burton's two-part inquiry was not helpful to deciding cases, that it did not focus on the right things, and that it did not go far enough. ${ }^{18}$

Burton responded with a thoughtful, and I think persuasive, reply to Summers's critique, in which he characterized the difference in their methodologies - the difference that I am calling generational:

We want our language to call our attention to the facts that matter those that legitimately establish similarities with or significant differences from the precedents. ... We want to know which facts shall count for more than their truth because they are legally significant.

Language can perform this function in a number of ways in addition to 'positive definitions.' Professor Summers' preference for "lists of factors generally relevant to the determination" favors one form that could be employed, in theory. . . . A second form that could be employed, however, is the general description or model - a simplified representation of a complex reality. ... Unlike most lists of factors, the general description technique encourages us to focus on complex webs of relationships among the facts. ${ }^{19}$

Or, in the words of P.J. O'Rourke: “Complexities are fun to talk about, but, when it comes to action, simplicities are often more effective."20

In drawing attention to a generational shift in modes of scholarship, I do not wish to exaggerate it. Not everyone took the turn to unifying theory. Most notable among contracts scholars who did not are those associated with the Wisconsin Contracts Group ${ }^{21}$ and those who were attracted to relational theory. ${ }^{22}$ Nevertheless, both of these schools of thought grew out of the influence of two scholars who were born within four years of Robert Summers at the begin-

17. Robert S. Summers, The General Duty of Good Faith - Its Recognition and Conceptualization, 67 CORNELl L. REv. 810, 829-30 (1982).

18. See id. at 830-34.

19. Steven J. Burton, More on Good Faith Performance of a Contract: A Reply to Professor Summers, 69 Iowa L. REv. 497, 509-10 (1984).

20. P.J. O'Rourke, Eat The Rich: A Treatise on Economics 209 (1998); cf. Richard A. Epstein, Simple Rules for a Complex World (1995).

21. See, e.g., Stewart Macaulay et Al., Contracts: LaW in Action (1995).

22. See, e.g., Jay M. Feinman, The Last Promissory Estoppel Article, 61 FordhaM L. REv. 303 (1992). For a summary and critique of communitarian relational theory, see Randy E. Barnett, Conflicting Visions: A Critique of Ian Macneil's Relational Theory of Contract, 78 VA. L. REv. 1175 (1992). 
ning of the Great Depression: Stewart Macaulay and Ian Macneil.23

Summers has not been without his own influence, particularly on his Cornell Law School colleague and casebook coauthor, ${ }^{24}$ Robert Hillman. Hillman, a 1972 graduate of Cornell himself, began teaching in 1975 at the University of Iowa, where Steven Burton arrived two years later in 1977. They taught together for five years when, in a career move that starkly symbolizes his choice of scholarly models, Hillman left Iowa in $1983^{25}$ to join the faculty of Cornell and his mentor Robert Summers.

\section{Hillman's Critique of Contract Theory}

Over the past twenty-five years, Professor Hillman has made many valuable contributions to contracts scholarship, ${ }^{26}$ but early on he expressed his discomfort with what he labeled "modern contract theory." In 1988, five years after moving from Iowa to Cornell, he published an essay, The Crisis in Modern Contract Theory, ${ }^{27}$ in which he laid out a general critique of unifying theories, and which he has now expanded into a book, The Richness of Contract Law.

The title of Hillman's book is intended to emphasize the fact that contract law is far more complex and "rich" than modern unifying contract theories seem to acknowledge:

Contract law includes a rich combination of normative approaches and theories of obligation. It is divided by special rules for distinct kinds of contracts and is subject to many exceptions and counterprinciples. Despite its many dimensions, contract law is a credible, if not flawless, reflection of the values of the surrounding society. A highly abstract unitary theory illuminates contract law, but it cannot explain the entire sphere. [p. 6]

Contract law and theory include contradictions and distinctions. Subject to competing norms and distinct theories of obligation and to various exceptions within the main body of doctrine, and divided by special rules applying to distinct kinds of contracts, contract law does not fit neatly into any slot. A highly abstract core theory simply cannot account for an entire subject. Instead, contract law is a plausible, if

23. Summers was born in 1933; Macaulay in 1931; and Macneil in 1929.

24. See Robert S. Summers \& Robert A. Hillman, Contract and Related ObliGATION (2d ed. 1992).

25. The year after Hillman departed, Eric Anderson joined the Iowa faculty. Anderson's subsequent contracts scholarship is clearly in the mold of Steven Burton. See, e.g., Eric Anderson, A New Look at Material Breach in the Law of Contract, 21 U.C. DAvis L. Rev. 1073 (1988) (providing a unified theory of material breach).

26. See, e.g., Robert A. Hillman, Court Adjustment of Long-Term Contracts: Analysis Under Modern Contract Law, 1987 Duke L.J. 1. I included an excerpt from this article in my anthology, Perspectives on Contract Law. See BARNETr, supra note 1, at 357-68.

27. Robert A. Hillman, The Crisis in Modern Contract Theory, 67 Texas L. Rev. 103 (1988). 
not perfect, reflection of various normative choices of the surrounding society. [pp. 273-74; emphasis added, footnotes omitted]

Throughout the book, Hillman offers a number of useful insights about various issues of contract law and theory - as he has in his numerous law review articles - but in this review I shall be concerned with his overall theme: a general skepticism about "unifying" or "highly abstract" contract theories that fail to mirror the richness of contract law. In this regard, he stands in the "realist" tradition of the previous generation of contracts scholars. Hillman attempts to justify this stance by examining a number of doctrinal contexts: contract formation, unconscionability, and good faith. He considers a variety of theoretical approaches: promise theorists, reliance theorists, feminist theorists, efficiency theorists, relational theorists, and critical legal scholars.

But though Hillman professes to be concerned with unifying contract theories in general, he seems to be primarily troubled by theories with which he disagrees. For example, he offers no criticism of feminist theory and, indeed, accepts Mary Joe Frug's characterization of his own analysis as "feminine." 28 After ten pages of uncritical summary of contract theories by critical legal scholars, Hillman concludes that he finds the "CLS [critical legal studies] indeterminacy thesis" to be "quite persuasive," though, without elaborating, he adds, "[i]n the end, contract law is probably not as indeterminate as CLS wants to claim" (p. 209). His critique of relational theory is similarly tepid, dismissing numerous lengthy published criticisms of relationalism, which he dutifully cites, ${ }^{29}$ with a single unsupported sentence: "These criticisms seem to underestimate the judicial capacity to engage in a highly contextual investigation and to evaluate the relevant relational norms ...." (p. 260) though he allows that "one can overstate the conclusions suggested by relationalism" (p. 260).

28. Frug concluded that my approach "neatly fits the popular interpretation of . . . virtuous feminine attitudes toward justice" because it "is characterized by a concern for multiple objectives, by an appreciation of contextualized relationships, and by a desire to achieve flexibility and sharing in the administration of contract remedies." Moreover, my analysis "offer[s] a critique of the male model which is both powerful and also reminiscent of typical feminine criticisms of masculinity."

P. 160 (quoting Mary Joe Frug, Rescuing Impossibility Doctrine: A Postmodern Feminist Analysis of Contract Law, 140 U. PA. L. REv. 1029, 1036, 1037 (1992) (alterations in original)).

29. He cites the following criticisms of relationalism without identifying where any are mistaken (p. $259 \mathrm{nn} .82-85$ ): Michael J. Trebilcock, The Limits of Freedom of Con. TRACT 141-42 (1994); Barnett, supra note 22, at 1200; Steven J. Burton, Default Principles, Legitimacy, and the Authority of a Contract, 3 S. CAL. INTERDISC. L.J. 115, 142 (1992); Richard Craswell, The Relational Move: Some Questions from Law and Economics, 2 S. CAL. INTERDISC. L.J. 91, 103, 108, 111 (1993); Melvin A. Eisenberg, Relational Contracts, in Good Farth AND Fault in Contract Law 291 (Jack Beatson \& Daniel Friedmann eds., 1995). 
This is, unfortunately, a general tendency of this book. Theories with which Professor Hillman appears sympathetic are presented with little or no criticism beyond footnote citations to the published criticisms of others, whereas he takes to task those theories with which he disagrees. Professor Hillman is, of course, well within his rights to agree or disagree with particular theories - in short, to take sides in a theoretical debate. But this book purports to be about the deficiencies of abstract or general contract theory per se, which he formerly had referred to as in a "crisis." $30 \mathrm{He}$ attempts to claim a higher ground than those locked in "theoretical debate" ( $p$. 7). If that is truly his thesis, then it is only selectively applied.

Moreover, just as he neglects the richness of published criticisms of theories he likes, he overlooks the richness of contract theories with which he disagrees. This is evident in his treatment of the basis of contractual obligation. There, his rhetorical stance is to rise above the debate between Grant Gilmore's "death-of-contract" thesis and Charles Fried's theory of "contract-as-promise." Hillman's argument is that

neither school has offered a compelling and definitive theory. Although based in part on promissory principles, modern contract law is also tempered both within and without its formal structure by principles, such as reliance and unjust enrichment, which focus on fairness and the interdependence of parties rather than on parties' actual agreements or promises. Contract law is complex, contradictory, and, ultimately, inconclusive on what the relationship of these principles is and should be. Moreover, by ignoring or downplaying counter-principles and theories, some theorists camouflage contract's complexity and hence disguise its true nature. The theoretical debate therefore diverts the focus from the reality that promissory and nonpromissory principles share the contract law spotlight, and that this is all we can and need to know. 31

Throughout the book, Hillman speaks of the complexity of contract law as though anyone with whom he disagrees is unaware of this complexity. He does not seem to realize that one function of contract theory is to understand and sort out complexity rather than merely report it. Another is to assess contending principles and "counter-principles and theories" (p. 7), when contract law is "ultimately[] inconclusive on what the relationship of these principles is and should be" (p. 7). Still another function is to reshape and improve the law of contract, to move it beyond where it currently resides. Of course, Hillman really does understand all this. His own writings attempt these very objectives. This is merely an unfortu-

30. See Hillman, supra note 27.

31. Pp. 7-8 (footnotes omitted). In support of his claim that "some theorists camouflage contract's complexity and hence disguise its true nature," Hillman cites Ian Macneil, of whose abstract unifying contract theory Hillman offers no criticism. See p. 7 \& n.3. 
nate posture he assumes when speaking of theories with which he disagrees.

For someone concerned with complexities, however, Hillman offers what the "realist" generation might call a simplistic and reductionist presentation of the current state of "modern contract theory." Grant Gilmore wrote in 1974 and Charles Fried in 1981. Hillman's book was published in 1997, though Chapter One closely tracks his 1988 essay. In the intervening sixteen years, many others have weighed in on these matters.

In 1986, for example, I offered a "consent theory" of contractual obligation that differs from both Gilmore's and Fried's theories, ${ }^{32}$ though being closer to the latter than to the former. Far from ignoring the fact that "modern contract law is also tempered both within and without its formal structure by principles, such as reliance and unjust enrichment, which focus on fairness and the interdependence of parties" (p. 7), I surveyed the "core concerns of contract law"33 - "will, reliance, efficiency, fairness, bargain"34 and explained how, while each has merit, "none provides a comprehensive theory of contractual obligation." 35 What is needed, I suggested, is a "framework that specifies when one of these concerns should give way to another."36 I proposed the criterion of manifested intention to be legally bound, or "consent," as the best way to reconcile the competing demands of these disparate principles. ${ }^{37}$ Since then I have elaborated upon this approach, ${ }^{38}$ and it has been

32. See Randy E. Barnett, Some Problems with Contract as Promise, 77 Cornell L. Rev. 1022 (1992).

33. See Randy E. Barnett, $A$ Consent Theory of Contract, 86 Colum. L. Rev. 269, 271 (1986).

34. Id. Later I added "unjust enrichment" to this list. See Randy E. Barnett, ConTRACTS CASES AND DOCTRINE 637-38 (1995).

35. Barnett, supra note 33, at 271.

36. Id.

37. For a summary of how "consent to be legally bound" accomplishes this integration, see BARNETT, supra note 34 , at 651-54.

38. See, e.g., Randy E. Barnett, Contract Remedies and Inalienable Rights, 4 Soc. Prit. \& Poly. 179 (1986); Randy E. Barnett, . . . and Contractual Consent, 3 S. CAL. INTERDIsc. L.J. 421 (1993); Randy E. Barnett, The Function of Several Property and Freedom of Contract, 9 Soc. PHIL. \& Poly. 62 (1992); Randy E. Barnett, The Internal and External Analysis of Concepts, 11 CARDOzo L. REv. 525 (1990); Randy E. Barnett, Rational Bargaining Theory and Contract: Default Rules, Hypothetical Consent, the Duty to Disclose, and Fraud, 15 Harv. J.L. \& PuB. Poly. 783 (1992); Randy E. Barnett, Squaring Undisclosed Agency With Contract Theory, 75 CAL. L. REv. 1969 (1987); Randy E. Barnett \& Mary Becker, Beyond Reliance: Promissory Estoppel, Contract Formalities and Misrepresentation, 15 Hofstra L. Rev. 445 (1987). 
criticized insightfully, ${ }^{39}$ especially by Richard Craswell. ${ }^{40}$ While nearly all of these articles are cited by Hillman, none are discussed. ${ }^{41}$ In writing a book that purports to criticize the endeavor of "unifying contract theories," one has an obligation to address more comprehensively than Hillman does the richness of such theories, rather than to reduce all of them to either "promise or nonpromissory principles" and cite the existing literature without comment.

True, one could fault, as others have, my attempt to adjudicate the claims of these contending principles of core concerns of contract law. But the most important claim that Hillman makes in this regard is his denial that any such adjudication is needed. Recall his statement: "The theoretical debate therefore diverts the focus from the reality that promissory and nonpromissory principles share the contract law spotlight, and that is all we can and need to know" (pp. 7-8; emphasis added, footnotes omitted). While he is in good company in making such a claim, I think he is wrong. At a minimum, we should seek a theoretical reconciliation, if such can be had. Ironically, the failure to do so will blind us to the true complexities and richness of contract law, as it may have blinded Hillman to the complexities of promissory estoppel.

\section{PROMISSORY ESTOPPEL AND THE NEED FOR CONTRACT THEORY}

Not too long ago, I published a short essay, The Death of Reliance, ${ }^{42}$ in which I reported the scholarly consensus - including such diverse writers as Daniel Farber \& John Matheson, Juliet Kostritsky, Edward Yorio \& Steve Thel, Mary Becker, and Michael Kelly ${ }^{43}$ - that had emerged over the past fifteen years or so, that detrimental reliance was not the key to understanding the doctrine of promissory estoppel. The scholarly literature on that point strongly suggested that detrimental reliance was not necessary to a promissory estoppel theory; its existence was not alone sufficient to support a promissory estoppel theory; and the measure of recovery

39. See, e.g., TREBILCOCK, supra note 29, at 121, 184; Peter Benson, Abstract Right and the Possibility of a Nondistributive Conception of Contract: Hegel and Contemporary Contract Theory, 10 CaRdozo L. Rev. 1077, 1111 n.57 (1989); Jean Braucher, Contract Versus Contractarianism: The Regulatory Role of Contract Law, 47 WASH. \& LEE L. REv. 697, 70308 (1990).

40. See Richard Craswell, Contract Law, Default Rules, and the Philosophy of Promising, 88 Mrch. L. Rev. 489, 523-28 (1989). For my reply, see Randy E. Barnett, The Sound of Silence: Default Rules and Contractual Consent, 78 VA. L. Rev. 821, 874-97 (1992).

41. See, e.g., p. 18 n.61 ("For another unitary theory of contract based on consent, see Randy E. Barnett [citing Columbia \& Virginia Law Review articles].").

42. Randy E. Barnett, The Death of Reliance, 46 J. LEGAL Educ. 518 (1996).

43. See id. at 522-27 (providing citations). 
in promissory estoppel cases was typically the expectation interest, not the reliance interest. In sum, those adhering to a "reliance theory" of promissory estoppel were barking up the wrong tree.

Hillman disagreed. In 1998, he published an article reporting his survey of "all of the reported decisions in the United States ... in which promissory estoppel was discussed from July 1, 1994 through June 30, 1996." 44 While he presents many interesting findings about the frequency and success of actions based on promissory estoppel, among them is one that challenges the scholarly consensus on promissory estoppel that $\mathrm{I}$ had summarized. Contrary to the "new consensus," reliance appears to be a definite requirement of promissory estoppel cases. The existence of reliance is discussed in 27 of $29(93.10 \%)$ of those cases in which a promissory estoppel action succeeds on the merits and in 32 of 57 (56.14\%) of those cases in which it survives a motion to dismiss. Where promissory estoppel actions fail, a defect in reliance is discussed in 151 of $270(55.93 \%)$ of the cases, and a defect in reliance alone is discussed in 68 of $270(25.19 \%)$ of the cases. 45

Curiously, while Hillman reports the total numbers of cases in which the absence of a promise (129), ambiguity of a promise (28), or refusal to accept parol evidence to prove the existence of a promise (8), was discussed as a reason for the failure of a promissory estoppel action, he does not provide the percentages of total cases these figures represent. And he does not provide the number of cases in which the defect in the promise was the only reason discussed by the court for the failure of a promissory estoppel claim. We can hazard a guess at these figures from his statement in a footnote that: "One or more reasons constituting a defect in the promise were discussed in half of the cases (135 cases). The court failed to discuss a defect in reliance in only 52 of those cases." 46 From this information we might surmise that in 135 (50\%) of the cases, one or more defects in the promise was discussed as the reason for the failure of a promissory estoppel claim, and in 83 of 270 $(30.74 \%)$ of the cases, the failure of a promise was the only reason discussed - as compared with the $25.19 \%$ of the cases in which a failure of reliance is the sole reason for denying recovery. From all this Hillman concludes that: "Overall, the picture that emerges is that neither promise nor reliance dominates as a judicial reason for the failure of promissory estoppel claims. Rather, both elements are crucial to recovery." 47

44. Robert A. Hillman, Questioning the "New Consensus" on Promissory Estoppel: An Empirical and Theoretical Study, 98 Colum. L. REv. 580, 582 (1998).

45. See id. at 589.

46. Id. at $599 \mathrm{n} .87$.

47. Id. at 599. 
Hillman's article is truly an important contribution to the promissory estoppel debate, and, for this reason, I have included two excerpts from it in the forthcoming edition of my casebook. His research shows that previous studies may well have been wrong to dismiss reliance as a necessary basis for recovery. On the other hand, the data might also mean that the absence of reliance was dispositive in only twenty-five percent of the cases in which promissory estoppel claims are denied. That undercuts the previous wisdom - still prevalent among most contracts professors - that detrimental reliance is the sine qua non of promissory estoppel.48 This conclusion is also supported by the facts that (a) defects in the promise are the only reason provided in $30.74 \%$ of the rejected promissory estoppel claims, and (b) detrimental reliance is not discussed at all in $44.07 \%$ of the cases in which promissory estoppel actions fail. Thus, reliance may well still be dead as the exclusive theory of promissory estoppel, which is how many contracts teachers still think of it.

Moreover, if one distinguishes promissory estoppel as a substitute for consideration (as Williston viewed it) from promissory estoppel as a cause of action distinct from breach of contract (as the court viewed it in Hoffman v. Red Owl Stores, 49 which many contracts scholars once considered to be the harbinger of the future), then Hillman's results favor Williston's theory. To get enforcement a plaintiff needs a "promise + something." That "something" could be a bargain (consideration), or it could be detrimental reliance (promissory estoppel); but, the plaintiff needs a promise in any event, and what results is a contract that presumably must still satisfy other contractual requirements, such as definiteness or the Statute of Frauds.

As interesting as what Hillman finds among the cases he studied, however, is what he may have missed - and why he might have missed it. Hillman looked only for discussions of reliance to show that, contrary to the "new consensus," its presence is essential to promissory estoppel actions. But the problem for advocates of a "reliance theory" of promissory estoppel has always been distinguishing reasonable, justified, or foreseeable reliance from unreasonable, unjustified, or unforeseeable reliance, for no contracts theorist thinks that any and all detrimental reliance justifies a promissory estoppel claim..$^{50}$ In other words, in addition to a promise, the plaintiff needs "reliance + something" to get a recovery under any reliance theory of promissory estoppel. Whatever that "some-

48. For a summary of the previous wisdom, see Barnett, supra note 42, at 518-22.

49. 133 N.W.2d 267 (Wis. 1965).

50. See, e.g., Restatement (SeCOND) OF Contracts $\S 90$ (1981) (referring to a "promise which the promisor should reasonably expect to induce" reliance by the promisee). 
thing" is, it cannot be reliance, which is present in any event. Thus, all reliance theories of promissory estoppel require appeal to some factor apart from reliance to distinguish enforceable promises (which are accompanied by reliance) from unenforceable ones, and this is an element that reliance theorists have been unsuccessful in identifying.

For this reason, it would have been helpful if Hillman had examined the cases in which the presence or absence of reliance was discussed, not only to "question[] the 'new consensus' on promissory estoppel," 51 but also to see if he could discern the qualities other than reliance that made reliance sufficient or insufficient. This would have required Hillman to be more sensitive to the nuances of contract theory than he appears to be when he claims in The Richness of Contract Law that "[ $\mathrm{t}] \mathrm{h}$ he theoretical debate therefore diverts the focus from the reality that promissory and nonpromissory principles share the contract law spotlight, and that is all we can and need to know." (pp. 7-8). If that is all we can know so be it, but it is hardly all we need to know.

Fortunately and coincidentally, at the time Hillman was conducting his research, another contracts scholar, Sidney DeLong, was conducting a very similar survey of decided promissory estoppel cases. In his article, The New Requirement of Enforcement Reliance in Commercial Promissory Estoppel: Section 90 as Catch-22,52 DeLong surveys "all of the promissory estoppel cases reported in 1995 and 1996."53 On this basis he, like Hillman, also takes issue with part of the "death of reliance" thesis I earlier presented.54

In particular, he confirms Hillman's principal finding that the presence of reliance is indeed a requirement of promissory estoppel: "A legion of unhappy plaintiffs can bear witness to the continued vitality of the actual reliance requirement, having discovered that a commercial promise is not alone sufficient to ground a claim under Section 90."55 $\mathrm{He}$ also confirms Hillman's claim that both reliance and a promise are needed to sustain an action for promissory estoppel: "It is true that in many cases, opinions affirming the

51. Hillman, supra note 44 .

52. Sidney W. DeLong, The New Requirement of Enforcement Reliance in Commercial Promissory Estoppel: Section 90 as Catch-22, 1997 Wis. L. Rev. 943.

53. Id. at 948.

54. His data "moderately" confirm the claim that the expectation interest, not the reliance interest, is the normal measure of recovery in contracts cases. See id. at 979-81. Hillman's data too undercut any claim that the reliance interest is the prevailing measure of damages in promissory estoppel cases. The expectation interest is regularly awarded. See Hillman, supra note 44 , at 601 .

55. DeLong, supra note 52, at 981; see also id. at 984 ("Every single opinion that mentioned the matter instead affirmed the Restatement requirement that the plaintiff actually rely .... Considered as a group, these holdings lay to rest Farber and Matheson's assessment that actual reliance is no longer an element of a claim of promissory estoppel."). 
necessity for reliance element also involved some other missing element. The most common defect was the absence of a clear and distinct promise ...."56 And he takes issue with my claim that a manifested intention to be legally bound should be sufficient for contractual enforcement even in the absence of a bargain or detrimental reliance. 57

DeLong's objective was not, however, simply to debunk the "new consensus" on promissory estoppel but also to refine existing general theories so as to understand better when reliance was sufficient to justify the enforcement of a promise and when it was insufficient. What he finds is intriguing: Courts appear to make a distinction between what DeLong terms "performance reliance" and "enforcement reliance." With performance reliance, the "promisee relies solely on her estimate of the likelihood that the promisor will perform, without any expectation of a legal remedy if the reliance is disappointed." 58 With enforcement reliance, the "promisee relies both on the credibility of the promise and on the belief that she will have a legal remedy for some or all of the costs of disappointed reliance if the promise is not performed." 59 While not claiming the existence of a judicial consensus on the matter, he does notice the following:

Many of the opinions reported in 1995 and 1996 lend support to the thesis that, in order to prevail on a promissory estoppel claim, a commercial promisee must now demonstrate not only that her reliance was reasonable in light of the likelihood that the promisor would perform [that is, performance reliance], but also that she had a reasonable belief that the promise was legally enforceable when made [that is, enforcement reliance]. Excluding those promises that are already enforceable under bargain contract theory, this requires that the promisor manifest an affirmative intention that the promise be en-

56. Id. at 985-86 (footnote omitted). This passage continues: "Many of the 1995-96 cases, however, denied promissory estoppel claims on the sole ground that plaintiff had not demonstrated actual, detrimental reliance. The absence of actual reliance was decidedly determinative, not merely make-weight, in these cases." Id. at 986-87 (footnote omitted).

57. For Barnett, ... the Section 90 promise becomes binding when it is made, regardless of the presence or absence of subsequent reliance by the promisee. Because he contends that actual reliance should be unnecessary to enforceability under Section 90, Barnett's consent theory cannot account for the courts' continuing insistence on actual reliance and their refusal to enforce non-bargain promises in its absence.

Id. at 995. But later, DeLong himself provides a possible answer to this challenge:

[U]nder Barnett's analysis a person who manifests an intention to be legally bound to perform a promise might also expressly or implicitly condition the promisee's power to enforce the promise on her actual reliance, or might expressly or implicitly reserve a power to rescind the promise at any time before such reliance.

Id. at 1000 .

58. Id. at 953. The passage continues: "The promisee decides whether and how much to rely by assessing the promisor's honesty and reliability, the circumstances bearing on the probability of performance and breach, the benefits that reliance followed by performance would confer, and the costs that disappointed reliance would impose." Id.

59. Id. 
forceable at the time of the promise. As the promise and consent theorists insist, the ensuing reliance is reasonable because the promise is enforceable, not vice versa. ${ }^{60}$

In sum, "the 1995-96 case sample contains several decisions suggesting that a manifestation of consent to be legally bound may be becoming essential to liability under Section 90."61 Moreover some "decisions support what might be called the negative half of the consent theory of Section 90 , which is both traditional and largely noncontroversial: one who expresses an intention not to be legally bound usually will not be."62

One way to demonstrate the richness of contract theory and its importance to understanding contract law, then, is simply to read both Hillman's and DeLong's articles and ask which tells one more about contract law. Of course, Hillman can always go back and reexamine his data to see if it confirms DeLong's findings. ${ }^{63}$ But this would only be to demonstrate that knowing "that promissory and nonpromissory principles share the contract law spotlight" (p. 8), was not all he needed to know to understand the richness of contract law.

Another way is to examine Hillman's treatment of promissory estoppel in The Richness of Contract Law. The book contains none of the empirical information just discussed, but it is clear that Hillman disagreed with those who emphasized promise over reliance before he embarked upon his study. In his chapter "Theories of Promissory Estoppel: Reliance and Promise," he takes issue with "promise theorists" - in particular, Farber \& Matheson ${ }^{64}$ and Yorio \& Thel. He offers one interesting insight in response to Yorio \& Thel's claim that reliance theory cannot explain the courts' insistence on the existence of a promise:65 "But Section 90 focuses on promise-induced reliance because other theories, such as equitable estoppel and misrepresentation, already protect injured parties

60. Id. at 1003. The passage continues:

Although the promisor's manifestation of intention to be bound is critical to these cases, the court's focus is usually on the promisee's actual or presumed understanding of that manifestation. Enforcement is denied if the court finds that the promisee was or should Id. have been aware that the promise was not intended to create an enforceable obligation.

61. Id. at 994.

62. Id. at 995 .

63. Hillman notes that "Professor Sydney W. DeLong's impressive study of promissory estoppel cases was published too late to be discussed in this Article." Hillman, supra note 44, at 581 n.3.

64. The article he criticizes is Daniel A. Farber \& John H. Matheson, Beyond Promissory Estoppel: Contract Law and the "Invisible Handshake," 52 U. CHI. L. Rev. 903 (1985).

65. See Edward Yorio \& Steve Thel, The Promissory Basis of Section 90, 101 YALE L.J. 111, 161-62 (1991) ("[R]eliance theory does not explain why in Section 90 cases courts insist that there be a promise. If the basis of recovery were harm caused by the defendant's conduct, it should not matter whether the conduct constituted a promise." (footnote omitted)). 
from conduct and statements inducing detrimental reliance. Promissory estoppel plugs the gap in liability by creating liability for promise-induced reliance" (p. 68). Mostly, however, he questions their interpretation of, or overgeneralization from, the cases they discuss - a critique that is considerably less persuasive, as a descriptive matter, than his later empirical study.

Hillman's need for an enriched theory of promissory estoppel is most apparent whenever he moves beyond describing judicial decisions to make normative suggestions for how courts ought to treat cases. For example, when discussing the need to distinguish reliance that merits protection from that which does not - the critical stumbling block for reliance theories of promissory estoppel - he says: "Foreseeability of the reliance seems a reasonable tool for distinguishing detrimental reliance that should and should not be compensated" (p. 68; emphasis added). No reason for this intuition is provided. He says:

Courts should also consider a promisor's good faith, for example, by taking into account the reasons for the broken promise. A court, with some justification, may want to punish a bad faith promisor by awarding expectation damages. Conversely, if a promisor acted in good faith and expectancy damages vastly exceed reliance damages, a court may choose the latter. [p. 76; emphases added, footnote omitted] No justification for these recommendations is given. He says:

Courts should evaluate defenses to bargained-for contracts more fully, for example, before they subvert them by granting expectancy damages under promissory estoppel. A court may conclude that a defense has outlived its usefulness and therefore decide the case on bargain grounds. Alternatively, a court may validate a contract defense, but conclude that a promisee's reliance also merits some relief. [pp. 75-76; emphases added]

No guidance is offered as to when courts ought to choose one alternative or the other.

To support any of these normative suggestions, Hillman's concluding observation that "reliance theory creates a flexible, evolving, context-dependent obligation" (p. 77) is simply no substitute for a theory of promissory estoppel, such as that provided by Sydney DeLong. But it neatly captures the instincts of the "realist" generation of contracts scholars who preceded him.

\section{Conclusion: The Best Law School Subject}

When I was considering how I would write this review, I had decided to begin by making the provocative, and not entirely serious, claim that contracts was the best subject in which to specialize as a law professor. First, there are the merits of contracts scholarship. The signal-to-noise ratio in the contracts literature is extraordinarily high. Contracts scholarship is of uniformly excellent 
quality; I rarely fail to learn from any article on contract law I read, and contract law publications are not too numerous to keep up with. There is a lot of long-standing and intricate contract doctrine to understand and integrate, so doing contract theory is both hard and rewarding.

Probably because there are so few active contracts scholars at the most elite schools, contracts scholars seem to place a very low premium on the status or institutional affiliations of other contracts scholars. ${ }^{66}$ Everyone with something to say gets a real hearing. Though it is harder to place a contract article in elite journals, this also means that contracts scholars are accustomed to finding and taking seriously excellent articles in less prestigious journals. Moreover, as the discourse chronicled above suggests, contracts scholars take each other's ideas very seriously - testing and probing them with vigor. And I think real progress is made over time as a result of this scholarly exchange.

Then there are the advantages of teaching contracts. Contracts is a basic first-year course so we get to teach students when they are at their most engaged. At many schools, contracts still run through a full year, so we can teach it in greater depth than any onesemester course. Contracts is a course that raises fundamental questions of both justice and efficiency. In addition to the great debates among legal titans - Langdell, Holmes, Williston, Corbin, Cohen, Fuller, Llewellyn, Gilmore, Farnsworth, Macneil, Atiyah, Simpson, Horowitz, Fried, and the list goes on and on - there is a wonderful history of contract law to learn and teach. And the contracts literature includes more than the usual number of articles about the real story behind the classic contracts cases.

To my great surprise, however, by the time I sat down to write the review, I found that I had been preempted by none other than Robert Hillman and Robert Summers in an essay entitled The Best Law School Subject, ${ }^{67}$ in which they claim that "contract law is by far the best law school subject to teach and to learn."68 They ask:

What other subject contains such a wealth of theory, doctrine, and substantive reasoning? What other subject focuses so clearly on essential components of economic and other organization in our society,

66. One of the drawbacks to being a contracts scholar is that the more prestigious the law school, the less obligation there appears to be to hire contracts scholars to teach first-year contracts classes. The prejudice is that contracts is a course that "anyone can teach." While this is too bad for anyone seeking to climb the ladder, it helps ensure that, among contracts scholars, one's reputation depends less on one's affiliation and more on one's writings than in most other subjects. Another drawback is that one rarely gets invited to speak at other law schools on contract law topics, as compared with, say, the Ninth Amendment.

67. Robert A. Hillman \& Robert S. Summers, The Best Law School Subject, 21 SeAtrie U. L. REv. 735 (1998). This is a reply to a review of their casebook by Sydney DeLong. See Sydney W. DeLong, An Agnostic's Bible, 20 Seattle U. L. Rev. 295 (1997) (book review).

68. Hillman \& Summers, supra note 67 , at 735. 
namely private agreements and exchange transactions? What subject better exemplifies the power of general theory, the functions and limits of the common law, the rise of statutory law, the interaction of rights and remedy, and the role of various legal actors in our system (including transactors, lawyers in their various roles, judges, and lawmakers)? ${ }^{69}$

Moreover they emphasize how much fun it is to teach contracts, in part perhaps because "students come to the subject with low expectations. Invariably they are more than pleasantly surprised to see how interesting and exciting it is to learn about what promises society legally enforces and why." 70

On this issue, then, there is no generational conflict. And I would add that, despite our disagreements, having active scholars like Robert Hillman with whom to exchange proposals and criticisms makes doing contracts theory both a challenge and a joy.

69. Id. at 735 (footnote omitted). In his review, DeLong observes that Hillman and Summers's casebook "offers no hope of rationalizing the [ ] different principles [of obligation] with each other or establishing authoritative ways of deciding cases when the principles come into conflict" and characterizes this as "both a strength and a weakness." DeLong, supra note 67, at 307. Hillman and Summers respond that they never attempted "to resolve the conflicts among the theories in one grand revelation. Indeed, no one has yet formulated a satisfactory 'unified field theory of civil obligation' and we doubt that anyone ever will or could." Hillman \& Summers, supra note 67, at 737 (quoting DeLong).

70. Hillman \& Summers, supra note 67, at 735. 